\title{
Review
}

\section{Heterogeneous Myeloid Cells in Tumors}

\author{
Aixia Dou and Jing Fang *(1) \\ Department of Drug Discovery and Biomedical Sciences, University of South Carolina College of Pharmacy, \\ Columbia, SC 29208, USA; douaixia@gmail.com \\ * Correspondence: fang8@cop.sc.edu
}

check for updates

Citation: Dou, A.; Fang, J. Heterogeneous Myeloid Cells in Tumors. Cancers 2021, 13, 3772. https://doi.org/10.3390/ cancers13153772

Academic Editors: Takashi Matozaki and Timo K. van den Berg

Received: 29 June 2021

Accepted: 24 July 2021

Published: 27 July 2021

Publisher's Note: MDPI stays neutral with regard to jurisdictional claims in published maps and institutional affiliations.

Copyright: (C) 2021 by the authors. Licensee MDPI, Basel, Switzerland. This article is an open access article distributed under the terms and conditions of the Creative Commons Attribution (CC BY) license (https:// creativecommons.org/licenses/by/ $4.0 /)$.
Simple Summary: It is well known that lymphocytes play a key role in the immunosurveillance for tumors. Accumulating evidence indicates that myeloid cells also have a large impact on tumor development. The tumor-associated myeloid cells (TAMCs) are heterogeneous and exert distinct and even opposing effects on tumor cells and tumor microenvironment (TME). In addition, myeloid cells play a critical role in modulating the behavior of lymphocytes, resulting in immunostimulatory or immunosuppressive TME cues that stimulate or suppress tumor development. Based on the function of myeloid cells in tumors, there are pro-tumor and anti-tumor myeloid cells. They are involved in pleiotropic processes, including growth, survival, differentiation, stemness, invasiveness, dissemination and metastasis of tumor cells, angiogenesis, remodeling of TME, immunomodulation, and response to cancer therapy. Understanding the function and mechanism of TAMCs in tumors will shed light on uncovering novel therapy.

Abstract: Accumulating studies highlight a critical role of myeloid cells in cancer biology and therapy. The myeloid cells constitute the major components of tumor microenvironment (TME). The most studied tumor-associated myeloid cells (TAMCs) include monocytes, tumor-associated macrophages (TAMs), dendritic cells (DCs), cancer-related circulating neutrophils, tumor-associated neutrophils (TANs), and myeloid-derived suppressor cells (MDSCs). These heterogenous myeloid cells perform pro-tumor or anti-tumor function, exerting complex and even opposing effects on all stages of tumor development, such as malignant clonal evolution, growth, survival, invasiveness, dissemination and metastasis of tumor cells. TAMCs also reshape TME and tumor vasculature to favor tumor development. The main function of these myeloid cells is to modulate the behavior of lymphocytes, forming immunostimulatory or immunosuppressive TME cues. In addition, TAMCs play a critical role in modulating the response to cancer therapy. Targeting TAMCs is vigorously tested as monotherapy or in combination with chemotherapy or immunotherapy. This review briefly introduces the TAMC subpopulations and their function in tumor cells, TME, angiogenesis, immunomodulation, and cancer therapy.

Keywords: monocytes; tumor-associated macrophages; dendritic cells; cancer-related circulating neutrophils; tumor-associated neutrophils; myeloid-derived suppressor cells; tumors; tumor microenvironment; angiogenesis; immunomodulation; chemotherapy; immunotherapy

\section{Introduction}

Lymphocytes and myeloid cells belong to the adaptive and innate immunity, respectively, defending microbial infection. Mounting evidence suggest that the immune system also plays an essential role at all stages of the development and metastasis of tumors [1,2]. Lymphocytes have been known as the major immunosurveillance for cancer cells. Myeloid cells are also implicated in cancer biology, exerting both pro-tumor and anti-tumor effects. These tumor-associated myeloid cells (TAMCs) regulate the proliferation, survival, stemness, invasiveness and dissemination of tumor cells, promoting or inhibiting tumor development, and metastasis [3,4]. These myeloid cells also regulate tumor progression and 
metastasis through reshaping tumor microenvironment (TME) and modulating vasculogenesis and angiogenesis [5-8]. In addition, TAMCs exert pleiotropic effects on lymphocytes, including recruitment of lymphocytes to TME, enhancement or suppression of the proliferation, differentiation, maturation, activation, and function of lymphocytes, leading to immune response, immune anergy, immune tolerance or immunosuppression [9-12]. Myeloid cells also largely impact on the response to cancer therapy [13,14]. TAMCs are a heterogenous group of mature and immature myeloid cells and the most studied populations include monocytes, tumor-associated macrophages (TAMs), dendritic cells (DCs), cancer-related circulating neutrophils, tumor-associated neutrophils (TANs), and myeloid-derived suppressor cells (MDSCs). These myeloid cells circulate peripheral blood or reside in tissues and are recruited to TME in response to cytokines, chemokines, or mediators secreted by tumor cells, immune cells, or stromal cells in TME [15]. Each of the myeloid cell population is also heterogenous and consists of distinct subsets involved in pro-inflammatory or anti-inflammatory response to microbial infections. Different subsets of myeloid cells also perform pro-tumor or anti-tumor function during tumor development and metastasis. Factors such as cytokines, chemokines, and metabolites in TME also regulate the proliferation, survival, differentiation, and maturation of circulating and infiltrated myeloid cells and reprogram them towards immunosuppressive and pro-tumor properties $[16,17]$. We aim to summarize the main subpopulations of TAMCs and their physiological functions and how they regulate tumor development and metastasis and response to cancer therapy.

\section{Monocytes}

\subsection{Subsets of Monocytes in Physiological Processes}

Monocytes are a heterogeneous group of mononuclear phagocytes that circulate peripheral blood and function as innate immunity during inflammation. The majority of circulating monocytes are classical monocytes that express $\mathrm{CD} 14^{+} \mathrm{CD} 16^{-}$in humans and Ly6 $\mathrm{C}^{\text {high }}$ in mice [18]. After differentiation from the lineage-committed progenitor cells, the common monocyte progenitor (cMoP) $[19,20]$, classical monocytes exit the bone marrow, following the gradients of chemokines, such as C-C motif chemokine ligand 2 (CCL2) and C-C motif chemokine ligand 7 (CCL7), through expressing chemokine receptors, including C-C motif chemokine receptor 2 (CCR2) [21,22]. During homeostasis, circulating classical monocytes convert to intermediate monocytes that express $\mathrm{CD} 14^{+} \mathrm{CD} 16^{+}$in humans and Ly6 $\mathrm{C}^{\text {int }}$ in mice, and subsequently convert to nonclassical monocytes that express $\mathrm{CD} 14^{\text {low }} \mathrm{CD} 16^{+}$in humans and Ly6C $\mathrm{C}^{\text {low }}$ in mice $[23,24]$. Upon infection, classical monocytes rapidly extravasate to inflamed tissues in response to chemokines, cytokines, and complement fragments; and mediate antimicrobial effects, such as phagocytosis [21,25].

\subsection{Function of Monocytes in Tumors}

At different stages of tumor development, different subsets of monocytes exhibit diverse and even opposing effects (Figure 1). Treatment with interferon gamma (IFN- $\gamma$ ) or interferon alpha (IFN- $\alpha$ ) upregulates the expression of tumor necrosis factor-related apoptosis-inducing ligand (TRAIL) but downregulates the expression of TRAIL receptor 2 in human monocytes [26]. TRAIL mediates apoptosis of cancer cells without injuring monocytes [26]. Following stimulation with tumor cells, human $\mathrm{CD} 14^{+} \mathrm{CD} 16^{+}$monocytes increase the production of pro-inflammatory cytokines tumor necrosis factor alpha (TNF$\alpha$ ) and interleukin 12 (IL-12) but reduce the production of anti-inflammatory cytokine interleukin 10 (IL-10), and exert direct cytotoxicity of tumor cells [27]. In the presence of anti-tumor monoclonal antibody $(\mathrm{mAb})$, human monocytes cultured with macrophage colony-stimulating factor (M-CSF, also referred as CSF-1) phagocytose melanoma and neuroblastoma tumor cells, a process known as 'antibody-dependent cellular cytotoxicity' (ADCC) [28]. CD16, also known as Fc $\gamma$ RIII, is the receptor of Fc domain of immunoglobulin $\mathrm{G}(\mathrm{IgG})$. Engagement of CD16 in response to mAb-coated tumor cells induces the secretion 
of TNF- $\alpha$ that mediate cell death of tumor cells expressing TNF- $\alpha$ receptor [29]. These studies reveal that monocytes exhibit tumoricidal activity.

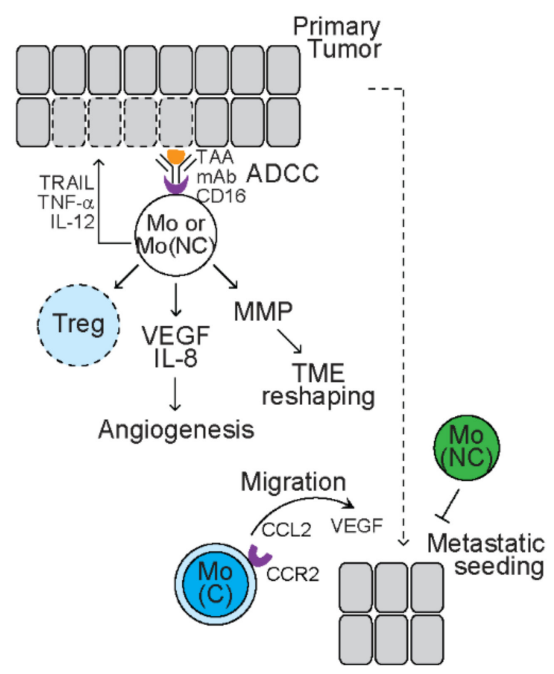

Figure 1. The function of monocytes in tumors. Light blue circles represent human immune cells with pro-tumor function. Dark green circles represent mouse immune cells with anti-tumor function. Dark blue circles represent mouse immune cells with pro-tumor function. White circles represent human immune cells with both anti-tumor and pro-tumor function. Cells with dashed lines represent dead cells. Monocytes (Mo) mediate cytotoxicity of tumor cells through secreting tumor necrosis factorrelated apoptosis-inducing ligand (TRAIL), tumor necrosis factor alpha (TNF- $\alpha$ ), and interleukin 12 (IL-12) and antibody-dependent cellular cytotoxicity (ADCC). Monocytes promote angiogenesis through upregulating vascular endothelial growth factor (VEGF) and interleukin 8 (IL-8). Monocytes reshape tumor microenvironment (TME) through producing matrix metalloproteinases (MMP). Nonclassical monocytes (Mo(NC)) mediate cytotoxicity of regulatory T cells (Tregs). C-C motif chemokine receptor $(\mathrm{CCR} 2)^{+}$classical monocytes $(\mathrm{Mo}(\mathrm{C}))$ are recruited by $\mathrm{C}-\mathrm{C}$ motif chemokine ligand 2 (CCL2) and promote metastatic seeding by secreting VEGF, while Mo(NC) reduce metastasis. TAA: tumor-associated antigen; mAb: monoclonal antibodies.

In addition, nonclassical monocytes mediate cytotoxicity of regulatory $\mathrm{T}$ cells (Tregs), a group of $\mathrm{CD}^{+}$helper $\mathrm{T}$ (Th) cells with immunosuppressive function, in vitro in an Fc $\gamma$-dependent manner [30]. Circulating monocytes from patients and mice with renal cell carcinoma (RCC) display a pro-tumor gene signature with upregulated expression of proangiogenic factors interleukin 8 (IL-8) and vascular endothelial growth factor (VEGF), as well as matrix metalloproteinases (MPPs), including MMP19 and MMP10 [31]. Functional studies reveal that media from RCC monocytes facilitate angiogenesis that is reversed by blocking VEGF receptor 2 (VEGFR2), indicating that RCC monocytes exert a VEGF-dependent proangiogenic property [31]. In addition, media from RCC monocytes facilitate invasiveness of RCC cells that is reversed by MMP inhibitors, indicating that RCC monocytes promote tumor cell invasion through reshaping TME.

In syngeneic mice bearing mammary tumors with spontaneous pulmonary metastases, $\mathrm{Gr}^{+} \mathrm{Ly}_{6 \mathrm{C}} \mathrm{C}^{+}$mouse classical monocytes are recruited to the pulmonary metastases, which is dependent on CCL2/CCR2 signaling [15]. In nude mice bearing metastatic breast cancer cells, $\mathrm{CD} 14^{+} \mathrm{CD} 16^{-}$human classic monocytes are also preferentially recruited to the lungs [15]. Blockade of the CCL2/CCR2 signaling axis inhibits the recruitment of mouse and human classical monocytes to the lungs, leading to less metastasis and prolonged survival time of tumor-bearing mice [15]. Mechanistically, classical monocytes produce VEGF that promotes extravasation of tumor cells, leading to metastatic seeding [32]. In comparison, nonclassical monocytes are activated after engulfing tumor cell-derived microparticles, leading to reduced metastasis of tumor cells to lungs [33]. These studies 
suggest that classical monocytes exert pro-metastatic effects, while nonclassical monocytes exert anti-metastatic effects.

\section{Tumor-Associated Macrophages (TAMs)}

\subsection{Subpopulations of Macrophages in Physiological Processes}

Tissue resident macrophages serve as the mononuclear phagocyte system, playing a critical role in tissue homeostasis and inflammation [34]. Mouse macrophages are derived from embryonic precursors during embryogenesis and locally self-renew or from circulating monocytes that are released from the bone marrow [35,36]. Macrophages are functionally heterogeneous and divided into two main subpopulations, M1 and M2 macrophages (Figure 2A) [37-39]. In response to lipopolysaccharide (LPS), IFN- $\gamma$ and granulocyte-macrophage colony stimulating factor (GM-CSF), M1 macrophages undergo classical activation and preferentially secrete antimicrobial molecules and pro-inflammatory cytokines, including reactive oxygen species (ROS), nitric oxide (NO), and interleukin 6 (IL-6) $[39,40]$. M1 macrophages function as the first line defense to fight microbial infections [39-41]. M1 macrophages also maintain strong antigen presenting capacity that induces strong Th1 response [39-41]. In response to interleukin 4 (IL-4), interleukin 13 (IL13), IL-10, and CSF-1, M2 macrophages undergo alternative activation and preferentially secrete anti-inflammatory cytokines, including transforming growth factor beta (TGF- $\beta$ ) and IL-10 as well as proteinases (i.e., arginase-1 and MPPs) [40,42]. M2 macrophages play a key role in limiting immune responses, while inducing angiogenesis and tissue repair [43]. Compared to mouse macrophages, human macrophages are less studied. In the presence of LPS and IFN- $\gamma$, circulating human macrophages are polarized to M1, secreting C-X-C motif chemokine ligand 10 (CXCL10), IFN- $\gamma$, IL-8, TNF- $\alpha$, and interleukin 1 beta (IL-1 $\beta$ [44]. In the presence of IL-4 and IL-13, human macrophages are polarized to M2, secreting IL-13, C-C motif chemokine ligand 17 (CCL17) and C-C motif chemokine ligand 18 (CCL18) [44]. In response to LPS, mouse macrophages mainly depend on glycolysis for energy, while human macrophages mainly rely on cellular respiration [45]. In response to IL-4, human and mouse macrophages exhibit overlapping and distinct gene signatures [46]. These indicate that human and mouse macrophages perform conserved as well as distinct functions, which needs further investigation.

\subsection{Recruitment and Polarization of TAMs in TME}

In patients with triple-negative breast cancer, the accumulation of $\mathrm{CD}^{+} 8^{+}$infiltrating macrophages is correlated with a higher risk of metastasis and shortened survival time [47], indicating that TAMs serve as a marker of unfavorable prognosis. The number of CD163 ${ }^{+}$ M2-like macrophages increases in bone marrow of patients with acute myeloid leukemia (AML) or multiple myeloma (MM) $[48,49]$. In patients with T-cell leukemia/lymphoma, the accumulation of $\mathrm{CD}^{+} 8^{+} \mathrm{CD} 163^{+} \mathrm{M} 2$-like macrophages is associated with worse clinical outcome [50]. In leukemia mouse models driven by expression of leukemic oncogenes, such as MLL-AF9, AML1-ETO9a, or NUP98-HOXD13, infiltration of macrophages, identified as $\mathrm{CD} 11 \mathrm{~b}^{\text {high }} \mathrm{Gr} 1^{\text {int }}$ or $\mathrm{CD} 11 \mathrm{~b}^{+} \mathrm{Ly} 6 \mathrm{G}^{-}$cells, in bone marrow and spleens inversely correlates with the survival of mice [48]. In contrast, in patients with non-small cell lung cancer (NSCLC), the density of $\mathrm{CD}^{+} 8^{+} \mathrm{HLA}-\mathrm{DR} \mathrm{R}^{+} \mathrm{M} 1$-like macrophages in tumor islets is associated with extended survival time [51]. Therefore, the presence of M2-like TAMs is associated with pro-tumor activity, while the presence of M1-like TAMs is associated with anti-tumor activity. 


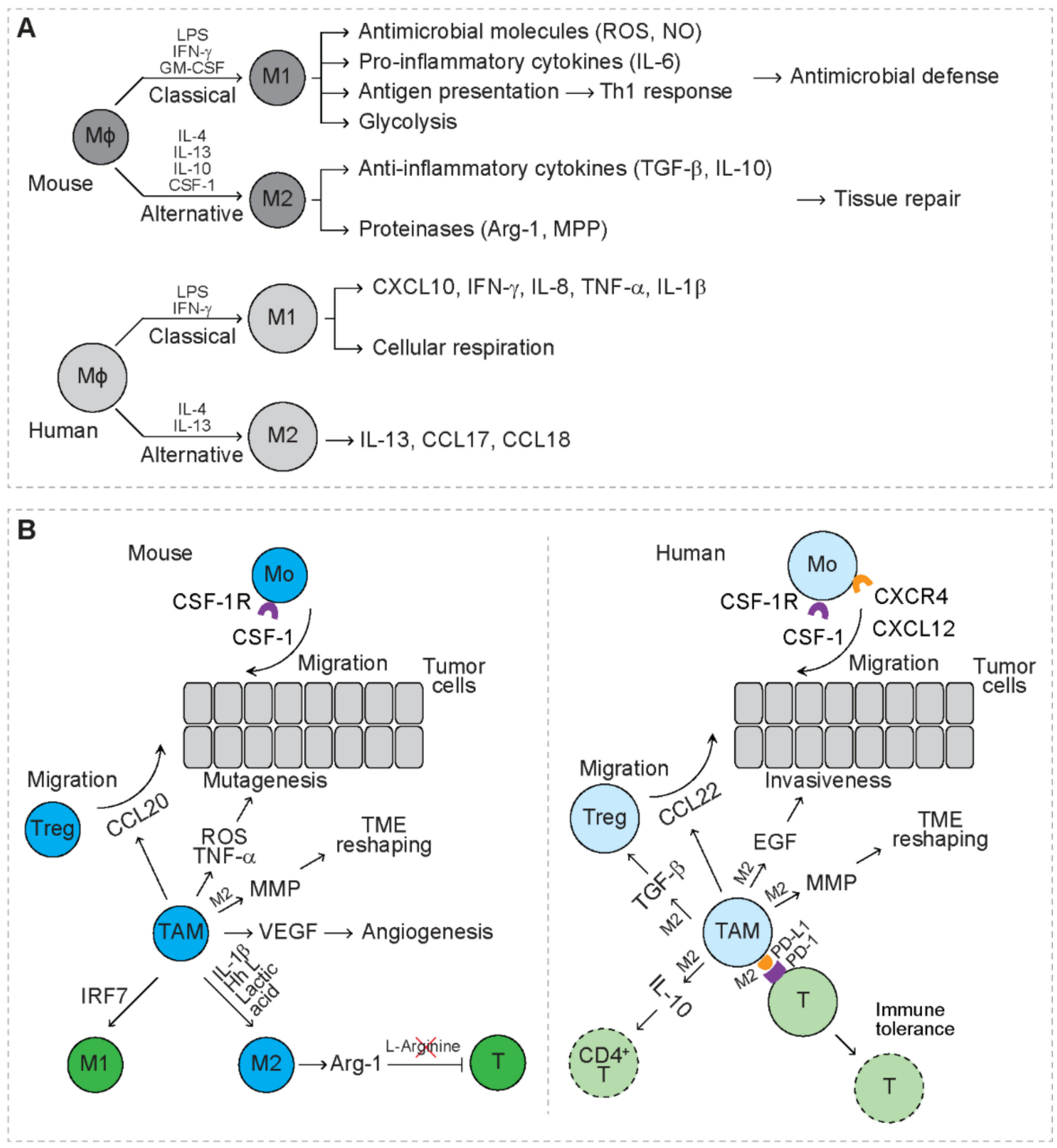

Figure 2. The function of TAMs in tumors. (A) Subpopulations of macrophages in physiological processes. Dark grey circles represent mouse macrophages. Light grey circles represent human macrophages. After classical activation, macrophages $(\mathrm{M} \phi)$ are polarized to M1 macrophages (M1); after alternative activation, macrophages are polarized to M2 macrophages (M2). LPS: lipopolysaccharide; IFN- $\gamma$ : interferon gamma; GM-CSF: granulocyte-macrophage colony-stimulating factor; ROS: reactive oxygen species; NO: nitric oxide; IL-6: interleukin 6; IL-4: interleukin 4; IL-13: interleukin 13; IL-10: interleukin 10; CSF-1: macrophage colony-stimulating factor; TGF- $\beta$ : transforming growth factor beta; Arg-1: arginase- 1 ; MMP: matrix metalloproteinases; CXCL10: C-X-C motif chemokine 10; IL-8: interleukin 8; TNF- $\alpha$ : tumor necrosis factor alpha; IL-1 $\beta$ : interleukin 1 beta; CCL17/18: C-C motif chemokine ligand 17/18. (B) Mouse (left) and human (right) macrophages in tumors. Dark green circles represent mouse immune cells with anti-tumor function. Dark blue circles represent mouse immune cells with pro-tumor function. Light green circles represent human immune cells with anti-tumor function. Light blue circles represent human immune cells with pro-tumor function. Cells with dashed lines represent dead cells. Macrophage colony-stimulating factor 1 (CSF-1)/macrophage colony-stimulating factor 1 receptor (CSF-1R) axis mediates recruitment of mouse and human monocytes (Mo) to tumors. C-X-C chemokine ligand 12 (CXCL12)/ C-X-C motif chemokine receptor 4 (CXCR4) axis mediates recruitment of human monocytes (Mo) to tumors. Mouse tumor-associated macrophages (TAM) are polarized to M1 or M2 macrophages depending on TME cues. M2 TAMs inhibit T cell function through upregulating programmed death-ligand 1 (PDL1) and secreting interleukin (IL-10). TAMs secrete C-C motif chemokine ligand 20 (CCL20) in mice and C-C motif chemokine ligand 22 (CCL22) in humans to recruit regulatory T cells (Treg). Human TAMs secrete TGF- $\beta$ to enhance Treg function. M2 TAMs express Arg-1 to inhibit T cell proliferation by depleting L-Arginine. Human TAMs secrete epidermal growth factor (EGF) to enhance invasiveness of tumor cells. Mouse and human TAMs secrete MMP to reshape tumor microenvironment (TME). Mouse TAMs secrete vascular endothelial growth factor (VEGF) to induce angiogenesis. 
Interaction of myeloma cells and bone marrow stromal cells (BMSCs) upregulates the production of C-X-C motif chemokine ligand 12 (CXCL12), leading to increased recruitment of human monocytes expressing C-X-C motif chemokine receptor 4 (CXCR4) to myeloma TME (Figure 2B) [49]. Blockage of CXCR4 largely inhibits the recruitment of monocytes to myeloma-derived medium [49], indicating that circulating monocytes serve as the main source of TAMs. In patients with breast cancer, upregulation of CSF-1 and CSF-1 receptor (CSF-1R) is associated with inferior prognosis [52]. In a mammary cancer mouse model, CSF-1 promotes the growth of breast cancer cells and metastatic potential through recruiting TAMs to TME [52]. In a pancreatic ductal adenocarcinoma mouse model, both circulating Ly6 $\mathrm{C}^{\text {high }}$ classical monocytes and tissue-resident macrophages contribute to the accumulation of TAMs in TME [53]. Once recruited to TME, TAMs are educated by specific TME cues, such as the molecules derived from tumor cells, stromal cells or immune cells (Figure 2B) [54,55]. In RCC-bearing mice, IL-1 $\beta$ secreted in TME reprograms TAMs towards an M2-like phenotype by downregulating the expression of interleukin 12B (IL12B) and nitric oxide synthase 2 (NOS2) and upregulating the expression of IL-10 and arginase-1 [31]. With an immunocompetent mouse model, breast cancer cells drive M2 polarization of TAMs through secreting Hedgehog (Hh) ligand [56]. Lactic acid, the end product of glycolysis, is produced by tumor cells and is shown to drive M2 polarization of TAMs via activation of the hypoxia inducible factor 1 subunit alpha (HIF-1 $\alpha$ ) signaling [17]. In leukemia mouse models, interferon regulatory factor 7 (IRF7) induces M1 polarization of TAMs, which is associated with prolonged survival of leukemia mice [57].

\subsection{Function of TAMs in Tumors}

TAMs create a mutagenic microenvironment that favors tumor initiation through secreting pro-inflammatory mediators, such as TNF- $\alpha$ and ROS (Figure 2B) [3,58]. In an intestinal cancer model, $\mathrm{H}_{2} \mathrm{O}_{2}$ produced by myeloid cells triggers DNA mutations, resulting in invasive growth of cancer cells [3].

In patients with NSCLC, expression of the immune checkpoint ligand, programmed cell death 1 ligand 1 (PD-L1), is upregulated in tumor-infiltrating immune cells (IC) that are enriched for M2-like TAMs [59]. NSCLC patients with PD-L1 ${ }^{+}$IC exhibit significantly lower disease-free survival rate and overall survival rate than those with PD-L1 ${ }^{-}$IC [59]. In patients with cholangiocarcinoma (CCA), TAMs are positive for PD-L1 and PD-L1 ${ }^{+}$ TAMs facilitate CCA progression in mouse model [60]. However, in patients with primary testicular lymphoma, the accumulation of PD-L1 ${ }^{+}$TAMs correlates with favorable survival [61]. Mechanistic studies reveal that expression of PD-L1 is upregulated on TAMs after exposure to lactic acid [62]. Interaction of PD-L1 with programmed cell death 1 (PD-1) on $\mathrm{T}$ cells inhibits $\mathrm{T}$ cell proliferation and induces $\mathrm{T}$ cell apoptosis, leading to immune tolerance (Figure 2B) [62]. TAMs from breast cancer patients suppress the expansion of $\mathrm{CD}^{+}$helper T cells by expressing PD-L1 and secreting the anti-inflammatory cytokine IL-10 [63]. TAMs of ovarian carcinoma patients secrete C-C motif chemokine ligand 22 (CCL22) to recruit Tregs, which is associated with reduced survival rate of the patients [64]. In mice bearing colorectal cancer, TAMs secrete C-C motif chemokine ligand 20 (CCL20) to recruit Tregs that promote the development of cancer [65]. In addition, human TAMs also secrete TGF- $\beta$ to enhance the function of Tregs through activation of the forkhead box p3 (Foxp3) signaling pathway [66]. In syngeneic tumor-bearing mice, M2 TAMs express arginase-1, leading to depletion of L-arginine that is required for T cell activation [67]. These studies suggest that TAMs are mainly immunosuppressive in cancer patients as well as tumor-bearing mice.

Human TAMs secrete epidermal growth factor (EGF) to potentiate the invasiveness of ovarian cancer cells (Figure 2B) [4]. Both human and mouse TAMs upregulate MMP that degrades interstitial collagen and upregulates the synthesis and assembly of collagens to remodel TME that favors invasion of tumor cells $[7,68,69]$. In RCC-bearing mice, TAMs produce pro-angiogenic factors, such as VEGF, and blocking of VEGFR2 abrogates angiogenesis, indicating that TAMs exert a VEGF-dependent pro-angiogenic effect [31]. In mice 
with breast cancer, TAMs are shown to recruit endothelial cells, fibroblasts, and pericytes for vasculogenesis in TME [8]. Accumulating data suggest that both human and mouse TAMs exert mainly pro-tumor effects.

\section{Dendritic Cells (DCs)}

DCs are the most potent antigen presenting cells (APCs), bridging innate immunity and adaptive immunity. DCs are ontogenetically heterogeneous. Some subsets of DCs, such as plasmacytoid DCs (pDCs), conventional DCs (cDCs) and monocyte-derived DCs (moDCs), are originated from common myeloid progenitors (CMPs) expressing fms-like tyrosine kinase 3 (Flt3), macrophage-DC progenitor (MDPs) or circulating monocyes, known as the myeloid origin [70]. Some subsets of DCs, such as pDCs and cDCs, are derived from Flt $3^{+}$commom lymphoid progenitors (CLPs) or T cell precursors, known as the lymphoid origin [70]. DCs are phenotypically and functionally heterogeneous under physiological conditions. In response to microbial infection, extracellular microbial proteins are generally phagocytosed or endocytosed by mature DCs and presented through class II major histocompatibility complex (MHC) molecules to $\mathrm{CD}^{+} \mathrm{T}$ cells. In contrast, cytosolic microbial proteins are generally presented through class I MHC molecules to $\mathrm{CD} 8^{+} \mathrm{T}$ cells (Figure 3A). DCs infiltrated in TME include different subsets of DCs at different developmental stages [71]. The presence of mature DCs in TME is usually associated with favorable prognosis in cancer patients as well as tumor-bearing mice [72-74]. These tumor-associated DCs exert immunostimulatory or immunosuppressive effects depending on the subset of DCs and stages of tumors (Figure 3) [71,75].

A

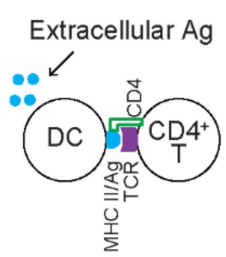

B

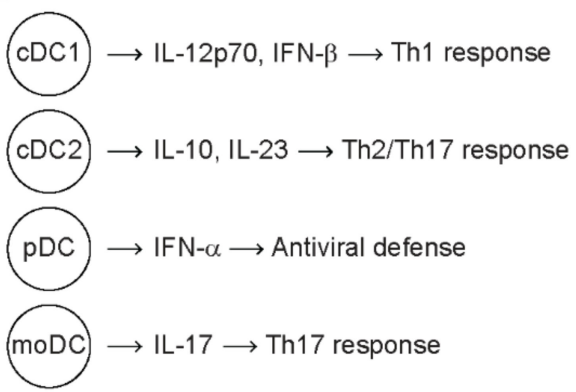

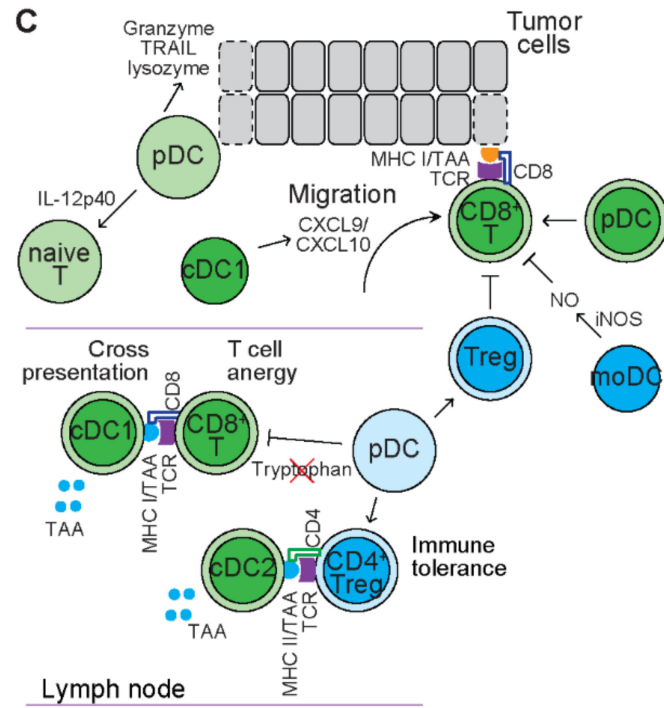

Figure 3. The function of DCs in tumors. (A) Antigen presentation of DCs. Extracellular antigens (Ag) are presented by class II major histocompatibility complex (MHC II) and recognized by CD4 ${ }^{+} \mathrm{T}$ cells. Cytosolic antigens are presented by class I MHC (MHC I) and recognized by CD8 ${ }^{+}$T cells. TCR: T-cell receptor. (B) Subpopulations of human DCs in physiological processes. cDC: conventional DCs; pDC: plasmacytoid DCs; moDC: monocyte-derived DCs; IL-12p70: interleukin 12p70; IFN- $\alpha$ : interferon beta; IL-10: interleukin 10; IL-23: interleukin 23; IFN- $\alpha$ : interferon alpha; IL-17: interleukin 17. (C) The function of DC subsets in tumors. Dark green circles represent mouse immune cells with anti-tumor function. Dark blue circles represent mouse immune cells with pro-tumor function. Light green circles represent human immune cells with anti-tumor function. Light blue circles represent human immune cells with pro-tumor function. Cells with dashed lines represent dead cells. In draining lymph node, $\mathrm{cDC} 1$ present extracellular tumor associated antigens (TAA) to CD8 ${ }^{+} \mathrm{T}$ cells through cross presentation. In tumor microenvironment (TME), $\mathrm{CDC1}$ secrete $\mathrm{C}-\mathrm{X}-\mathrm{C}$ chemokine ligand 9/10 (CXCL9/10) to recruit activated CD8 ${ }^{+} \mathrm{T}$ cells that recognize the same TAA on tumor cells and mediate cytotoxicity of tumor cells. cDC2 present extracellular TAA to CD4 ${ }^{+}$ regulatory T cells (Treg), leading to immune tolerance. pDCs induce pro-tumor immunity through sustaining expansion of Tregs but inhibiting proliferation of T cells through depleting tryptophan. pDCs also induce anti-tumor immunity through priming T cells and direct killing of tumor cells. moDCs suppress T cell proliferation through producing NO. 


\subsection{Conventional DCs and Their Function in Tumors}

Conventional DCs (cDCs), also known as classical DCs, consist of two phenotypically and functionally distinct subpopulations. Human $\mathrm{CDC} 1$ express CD11c, MHC-II, BDCA3, CD141, XCR1, CLEC9A, and DNGR1, while mouse CDC1 express CD11c, MHC-II, BDCA3, CD141, CD8a, and CD103 [76]. Human cDC1 express toll-like receptors (TLRs) and secrete pro-inflammatory cytokines, including interleukin 12p70 (IL-12p70) and interferon beta $(\mathrm{IFN}-\alpha)$, in response to infection to induce Th1 response [77]. $\mathrm{cDC} 1$ are observed within tumors and their presence is associated with favorable clinical outcome [72,78,79]. In tumorbearing mice, $\mathrm{CDC} 1$ in TME secrete chemokines, such as $\mathrm{C}-\mathrm{X}-\mathrm{C}$ motif chemokine ligand 9 (CXCL9) and CXCL10 to recruit effector T cells to TME [80]. Through a cross-presentation mechanism, both human and mouse $\mathrm{CDC} 1$ are capable of capturing extracellular proteins from tumor materials, processing tumor associated antigens (TAA) through class I MHC molecules and presenting to $\mathrm{CD} 8^{+} \mathrm{T}$ cells that mediate cytotoxicity of tumor cells [72,81-83]. In an immunocompetent melanoma mouse model, $\mathrm{CD} 103^{+} \mathrm{CD} 141^{+} \mathrm{cDC} 1$ that carry TAA migrate to draining lymph nodes (dLN) in a C-C motif chemokine receptor 7 (CCR7)dependent manner and present TAA to naïve $\mathrm{CD}^{+} \mathrm{T}$ cells residing in $\mathrm{dLN}$, leading to $\mathrm{T}$ cell priming [82]. Primed $\mathrm{CD} 8^{+} \mathrm{T}$ cells then activate, proliferate and differentiate into cytotoxic T cells and infiltrate TME [82]. These cytotoxic T cells recognize the same TAA presented by tumor cells and mediate cytotoxicity of tumor cells, leading to prolonged survival of tumor-bearing mice [82]. With human tumor samples and mouse tumor models, $\mathrm{CD} 103^{+} \mathrm{CDC} 1$ exhibit strong capacity to stimulate cytotoxic T cells, which is dependent on transcription factors, such as interferon regulatory factor 8 (IRF8), zinc finger and BTB domain containing 46 (Zbtb46) and basic leucine zipper ATF-like transcription factor (Batf3) [72]. These studies suggest that $\mathrm{CDC1}$ stimulate anti-tumor immune response. Consistently, $\mathrm{CDC} 1$ specific gene signatures are used as positive prognostic markers in cancer patients $[72,78,79]$.

cDC2 are more abundant and express CD11c, MHC-II, BDCA1, CD172a (signal regulatory protein alpha, SIRP $\alpha$ ), CD115 (CSF-1R), and CD11b [84]. Human CDC2 produce various cytokines, such as IL-10 and interleukin 23 (IL-23), and present antigens to CD4 ${ }^{+}$ helper T cells (Th), leading to activation of effector T cells, including Th2 cells and Th17 cells [85]. cDC2 identified in both human and mouse tumors are capable of capturing extracellular TAA proteins, processing through class II MHC molecules and presenting to $\mathrm{CD}^{+} \mathrm{T}$ cells [86]. A two-step priming model is proposed in that $\mathrm{CDC} 1$ prime $\mathrm{CD} 8^{+} \mathrm{T}$ cells while $\mathrm{cDC} 2$ prime $\mathrm{CD} 4^{+} \mathrm{T}$ cells in distinct regions of $\mathrm{dLN}$ [87]. In secondary immune response, the same $\mathrm{CDC} 1$ activates both $\mathrm{CD} 4^{+} \mathrm{T}$ cells and $\mathrm{CD} 8^{+} \mathrm{T}$ cells [88]. $\mathrm{CD} 4^{+} \mathrm{T}$ cells produce cytokines and provide costimulatory signals to promote clonal expansion of $\mathrm{CD} 8^{+}$ $\mathrm{T}$ cells and their differentiation into cytotoxic T cells and memory T cells [88]. Despite the observation that migratory $\mathrm{CDC} 2$ stimulate the priming, activaton and expansion of $\mathrm{CD} 4^{+}$ $\mathrm{T}$ cells, the effector T cells are mainly Tregs that suppress the function of $\mathrm{CDC} 2$ and result in immune tolerance [86]. Depletion of Tregs restores the function of $\mathrm{CDC} 2$, leading to differentiaton of primed $\mathrm{CD} 4^{+} \mathrm{T}$ cells to effector $\mathrm{T}$ cells that mediate anti-tumor immune response [86]. In the absence of Tregs, the amount of $\mathrm{CDC} 2$ correlates with the number of $\mathrm{CD}^{+} \mathrm{T}$ cells and responsiveness to checkpoint inhibitors [86]. In human and mouse lung cancer, expression of $\mathrm{CDC} 2$ gene signature is associated with positive prognosis [89]. Therefore, both $\mathrm{cDC} 1$ and $\mathrm{CDC} 2$ favor anti-tumor immunity.

\subsection{Plasmacytoid DCs and Their Function in Tumors}

DCs that share morphology with antibody-secreting plasma cells are known as pDCs. Human $\mathrm{pDC}$ are $\mathrm{CD} 123^{+} \mathrm{CD} 303^{+} \mathrm{CD} 304^{+} \mathrm{CD} 11 \mathrm{c}^{-}$, while mouse $\mathrm{pDC}$ are $\mathrm{CD} 11 \mathrm{c}^{\text {low }} \mathrm{B} 220^{+}$ $\mathrm{CD}_{11}{ }^{+}$Siglec- $\mathrm{H}^{+}$(sialic acid-binding immunoglobulin-like lectin $\mathrm{H}$ ) [76]. In response to viral infection, $\mathrm{pDCs}$ recognize viral nucleic acids via TLRs and secrete type I interferon IFN- $\alpha$ and play a key role in antiviral defense [90]. pDCs are observed in TME of cancer patients and are associated with early relapse and unfavorable clinical outcome [11,91-94]. In aggressive triple-negative breast tumor samples, pDCs colocalize with Tregs and ex- 
hibit partially activated phenotype with impaired IFN- $\alpha$ production upon engagement of TLRs [93]. Reduced production of IFN- $\alpha$ by tumor-infiltrating pDCs sustains the expansion of $\mathrm{FoxP}^{+}$Tregs in vivo, contributing to immune tolerance and progression of breast cancer [93]. Human head and neck squamouse cell carcinoma (HNSCC) cells dampen the function of pDCs through downregulating TLR expression, leading to reduced production of IFN- $\alpha$ and impaired T cell-mediated anti-tumor immune response [94]. pDCs are also found in tumor dLN in melanoma patients [92]. These dLN pDCs express indoleamine 2,3dioxygenase that deplete tryptophan (amino acids critical for $\mathrm{T}$ cell proliferation), leading to T cell anergy and immune tolerance [9]. This evidence suggests that pDCs induce an immunosuppressive immune response.

In addition to immunosuppressive effects, some studies reveal that $\mathrm{pDC}$ induce immunostimulatory response. $\mathrm{CD} 123^{+} \mathrm{pDCs}$ are located in peritumoral areas of primary melanomas in close contact with $\mathrm{CD} 8^{+} \mathrm{T}$ cells [95]. Functional assays reveal that both human and mouse $\mathrm{pDC}$ s prime $\mathrm{CD} 8^{+} \mathrm{T}$ cells, resulting in their activation and differentiaton to cytolytic and IFN- $\gamma$-producing effector T cells and regression of tumors in vivo $[95,96]$. Human CD2 ${ }^{\text {high }}$ pDCs infiltrated in TME express high levels of granzyme B, TRAIL and lysozyme, which limit proliferation of tumor cells and mediate contact-dependent killing of tumor cells [97]. In addition, CD2 ${ }^{\text {high }}$ pDCs are also efficient at secreting IL-12p40, which primes naïve T cells and results in T cell expansion and immune response [97]. Therefore, DCs exert both pro-tumor and anti-tumor effects during tumor development.

\subsection{Monocyte-Derived DCs and Their Function in Tumors}

In response to infection, circulating monocytes enter tissue and differentiate into DCs [98]. These DCs are known as moDCs or inflammatory DC (inf-DC), and express CD1a, BDCA1, CD11c, MHC II, and CD64 in humans and CD11b, CD11c, F4/80, CD64, FceRI $\alpha$, Ly6C, and MHC II in mice [76]. MoDCs are absent under homeostatic conditions, but observed in inflammatory cues, such as inflammaotory fluids, and secrete interleukin 17 (IL-17) to induce differentiation of naïve $\mathrm{CD}^{+} \mathrm{T}$ cells into Th17 cells [99]. MoDC are also observed in TME of certain cancers, such as lung cancer and breast cancer mouse models as well as human cancers [71]. With a lung carcinoma mouse model, CD64 ${ }^{\text {hi }} \mathrm{CD} 11 \mathrm{~b}^{+}$ MoDCs are observed in TME [71]. Adoptive transfer experiments reveal that tumorinfiltrating MoDCs are derived from $\mathrm{Ly}_{6} \mathrm{C}^{+}$bone marrow monocytes [71]. Deletion of CCR2 results in the lack of MoDCs in TME, indicating that migration of circulating $\mathrm{Ly}^{6} \mathrm{C}^{+}$ monocytes to TME is dependent on CCR2 [71]. Despite high efficiency in uptaking and processing antigens, MoDCs exhibit low efficiency on activating naïve T cells [71]. Instead, MoDCs are efficient at expressing TNF- $\alpha$ and inducible nitric oxide synthase (iNOS) [71]. MoDCs therefore phenotypically recapitulate the TNF- $\alpha$-iNOS-producing DCs (Tip-DCs) and iNOS-mediated production of NO suppresses T cell proliferation [71], indicating that MoDCs induce immunosuppressive response. With a lymphoma mouse model, the antitumor effect mediated by adoptively transferred $\mathrm{CD} 8^{+} \mathrm{T}$ cells is dependent on nitric oxide synthase 2 (NOS2) expressed by Tip-DCs [100]. Tip-DCs improve the anti-tumor effect of $\mathrm{CD}^{+} \mathrm{T}$ cells through mediating NO-dependent killing of lymphoma cells, indicating that Tip-DCs exert immunostimulatory effect. Accordingly, gene signatures of Tip-DCs are positively associated with genes expressed in active $\mathrm{CD} 8^{+}$cytotoxic $\mathrm{T}$ cells and survival of colorectal cancer patients [100]. The discrepancy between these two studies may be due to response of T cells and tumor cells to NO. Therefore, the function of MoDCs in tumors needs further study.

\section{Granulocytes}

\subsection{Cancer-Related Circulating Neutrophils}

Neutrophils are polymorphonuclear phagocytes that circulate peripheral blood and function as innate immunity against microbial pathogens. In patients with cancer, especially at advanced stages and after metastasis, the number of circulating neutrophils increases and high neutrophil-to-lymphocyte ratio (NLR) is associated with aggressive 
outcome [101-103]. Similarly, in tumor-bearing mice, the number of neutrophils also increases in peripheral blood and is also associated with aggressive outcome and metastatic potential $[104,105]$. These cancer-related circulating neutrophils comprise functionally heterogenous subsets (Figure 4). With Ficoll-Hypaque density gradient centrifugation, neutrophils are found in the high-density (HD) fraction (high-density neutrophils, HDNs), while mononuclear cells are found in the low-density (LD) fraction [105]. HDNs are a homogeneous group of mature, segmented neutrophils, expressing CD66b, CD11b, CD15, CD16, and CD10 in humans and CD11b, Gr1, and Ly6G in mice $[105,106]$. Neutrophils are also found in the LD fraction (low-density neutrophils, LDNs) [105]. LDNs are a heterogenous group of cells with two major subpopulations based on developmental stages-i.e., mature neutrophils that are derived from HDNs and immature MDSCs [105]. In tumor-free mice, over $95 \%$ of circulating neutrophils are HDNs [105]. In tumor-bearing mice, such as breast cancer, mesothelioma and lung cancer, the number of circulating neutrophils, especially LDNs, increases with tumor progression [105]. Increased proportion of LDNs is partly due to TGF- $\beta$-dependent sponteneous transition from HDNs, especially in mice bearing tumors in late-stages [105]. HDNs exhibit high levels of phagocytosis and mediate cytotoxicity of tumor cells in vitro [105]. In initial tumor growth, adoptive transfer of HDNs dramatically retards tumor growth in vivo [105]. In both spontaneous and experimental metastatic mouse models, $\mathrm{CD} 11 \mathrm{~b}^{+} \mathrm{MMP}^{+} \mathrm{HDNs}$ (also refered as tumor entrained neutrophils, TENs) accumulate in the pre-metastatic lung, and inhibit seeding of tumor cells in the pre-metastatic area through mediating direct cytotoxicity of tumor cells through releasing ROS [107]. In contrast, LDNs exhibit reduced ROS production, no cytotoxicity towards tumor cells and no significant effect on initial tumor growth [105]. Mechanistic studies reveal that LDNs induce a supportive TME through downregulating expression of pro-inflammatory cytokines and limiting proliferation of $\mathrm{CD} 8^{+} \mathrm{T}$ cells [105]. With a breast cancer mouse model, granulocyte colony-stimulating factor (G-CSF) derived from tumor cells is shown to reprogram neutrophils toward immunosuppressive LDNs [108]. These studies suggest that HDNs exert anti-tumor effects, while LDNs exert pro-tumor effects.

\subsection{Tumor-Associated Neutrophils (TANs)}

In addition to cancer-related circulating neutrophils, TANs also play a critical role in tumor development and metastasis (Figure 4). Most C-X-C motif chemokine receptor $2(\mathrm{CXCR} 2)^{+}$leukocytes in peripheral blood are neutrophils. In spontaeous tumor mouse models, inhibition of CXCR2 reduces the infiltration of $\mathrm{Ly} 6 \mathrm{G}^{+}$neutrophils and tumor formation [109]. In a Kras ${ }^{\mathrm{LAI}}$-driven lung adenocarcinoma mouse model, CXCR2 ligand, C-X-C motif chemokine ligand 8 (CXCL8), is a transcriptional target of Ras and induces progression of premalignant lesion that is associated with infiltration of neutrophils [110]. These studies suggest that CXCR2 mediates recruitment of neutrophils to primary tumor sites. In a mouse model recapitulating human pancreatic ductal adenocarcinoma, deletion or inhibition of CXCR2 abrogates metastasis [111]. In a breast cancer mouse model, metastasis of tumor cells to lung is abolished by inhibiting CXCR2, which is associated with reduced recruitment of neutrophils [112]. These studies suggest that CXCR2 also mediates recruitment of neutrophils to a premetastatic site.

Multiple studies demonstrate that TANs in TME promote proliferation, extravasation, and migration of tumor cells (Figure 4). With esophageal cancer cell lines, TANs are shown to release granule contents, such as elastase, to promote proliferation and invasion of cancer cells [113]. TANs are shown to promote dissemination of cancer cells by secreting IL-1 $\beta$ and MPPs to facilitate extravasation of tumor cells to premetastatic niches [114]. Cools-Lartigue et al. reveal that neutrophil extracellular traps (NET) catch circulating lung carcinoma cells, which activates TLR pathway to promote migration, adhesion, invasion and metastasis of tumor cells $[115,116]$. In addition to pro-tumor effects, TANs are also shown to mediate cytotoxicity of tumor cells through producing ROS and TRAIL [117,118].

The opposing effects of neutrophils on tumor development and metastasis implicate functional plasticity of neutrophil subsets (Figure 4). Neutrophils with anti-tumor 
effect are termed "N1" TANs, while neutrophils with pro-tumor effect are termed "N2" TANs [119]. Studies propose that TME impacts on the balance of N1 and N2 subpopulations through secreting cytokines that reprogram neutrophil differentiation. For example, TGF- $\beta$, IL-6, G-CSF and interleukin 35 (IL-35) are shown to induce pro-tumor polarization of TANs [119-121]. IFN- $\beta$ and IL-12 are shown to induce anti-tumor polarization of TANs [122,123]. Studies have also shown that TANs interact with lymphocytes in TME and regulate their functions. Natural killer (NK) cells function as immunosurveillance to clear tumor cells from dissemination during metastasis. In 4T1-bearing mice, N2 TANs inhibit NK cell-mediated clearance of tumor cells, thus promoting tumor metastasis [114]. N2 TANs secrete CCL17 to recruit Tregs into TME, thus promoting tumor growth [124]. In contrast, N1 TANs produce chemokines, such as C-C motif chemokine ligand 3 (CCL3, CXCL9, CXCL10), to recruit CD8 ${ }^{+} \mathrm{T}$ cells to TME and secrete cytokines (e.g., IL-12, TNF- $\alpha$, and GM-CSF) to activatethe cytotoxicity of $\mathrm{CD}^{+} \mathrm{T}$ cells [119], thus providing anti-tumor effect.

\subsection{Other Types of Granulocytes}

In addition to neutrophils (neutrophilic granulocytes), other types of granulocytes, such as eosinophilic granulocytes (eosinophils) and basophilic granulocytes (basophils), also impact on tumors. Eosinophils are known for their roles in defense againt helminth infections and allergic diseases. With co-culture system, both human and mouse eosinophils exhibit direct cytotoxicity to various cancer cells, such as mastocytoma, melanoma, and colon carcinoma [125-127]. Eosinophils also exhibit indirect cytotoxicity to cancer cells through secreting pro-inflammatory cytokines, such as TNF- $\alpha$ [128]. In mice bearing hepatocellular carcinoma, interleukin 5 (IL-5) activates eosinophils, leading to suppression of tumor growth [128]. In mice bearing melanoma, administration of interleukin 33 (IL-33) delays tumor growth and prevents pulmonary metastasis through recruiting and activating eosinophils [126]. Mechanistic studies reveal that IL-33 stimulates contactdependent degranulation of eosinophils and resultant killing of tumor cells [129]. In mice bearing melanoma, colorectal carcinoma, thymoma or lung carcinoma, transfer of eosinophils enhances recruitment of $\mathrm{CD}^{+} \mathrm{T}$ cells to suppress tumor growth that is associated with increased expression of pro-inflammatory cytokines, decreased expression of pro-angiogenic factors, and M1-like polarization of TAMs [130]. These studies indicate antitumor activity of eosinophils. Intriguingly, infiltration of eosinophils is observed in patients with cervical cancer [131]. Mechanistic studies reveal that thymic stromal lymphopoietin (TSLP) activates eosinophils that promote proliferation and survival of cervical cancer cells through upregulating Ki-67, proliferating cell nuclear antigen (PCNA) and BCL-2 and downregulating Fas and Fas ligand (FasL) [131]. In addition, TSLP stimulates eosinophils to produce VEGF and IL-8 that promotes angiogenesis in vitro [132]. Eosinophils also induce M2-like polarization of TAMs through secreting IL-13 [133]. These studies indicate a pro-tumor activity of eosinophils. In clinic, infiltration of eosinophils in TME correlates to favorable prognosis in patients with colonic carcinomas, oral squamous cell carcinomas, esophageal squamouse cell carcinoma, and nasopharyngeal carcinoma [134-137]. However, accumulation of eosinophils in tumors correlates with shorter survival time in patients with Hodgkin's disease, a group of B cell malignancies [138]. Discrepancies of eosinophilmediated immunity in tumors may be due to plasticity of eosinophils or heterogeneity of tumors, which needs further study.

Basophils are very rare in peripheral blood and are known to defend against parasites. Accumulation of basophils in bone marrow of patients with myelodysplastic syndrome (MDS), a pre-leukemia condition, is an independent prognostic factor for evolution to AML $[139,140]$. Growth of basophils from patients with chronic myeloid leukemia (CML) is associated with unfavorable prognosis and transformation to AML [141]. Mechanistic studies reveal that basophils secrete hepatocyte growth factor (HGF), leading to expansion of CML cells [142]. These studies indicate that basophils may be involved in disease evolution to high-risk hematologic malignancies. In contrast, colorectal cancer patients with low basophil count in peripheral blood exhibit shorter disease free survival time [143], 
indicating the anti-tumor potential of basophils. In addition, melanoma patients with high levels of basophils exhibit favorable overall survival after immunotherapy [144]. Breast cancer-bearing mice with low frequency of basophils in peripheral blood exhibit increased lung metastases [145]. Given the difficulty of deleting or depleting basophils in vivo, the function of basophils in tumors is still unclear and needs more investigation.

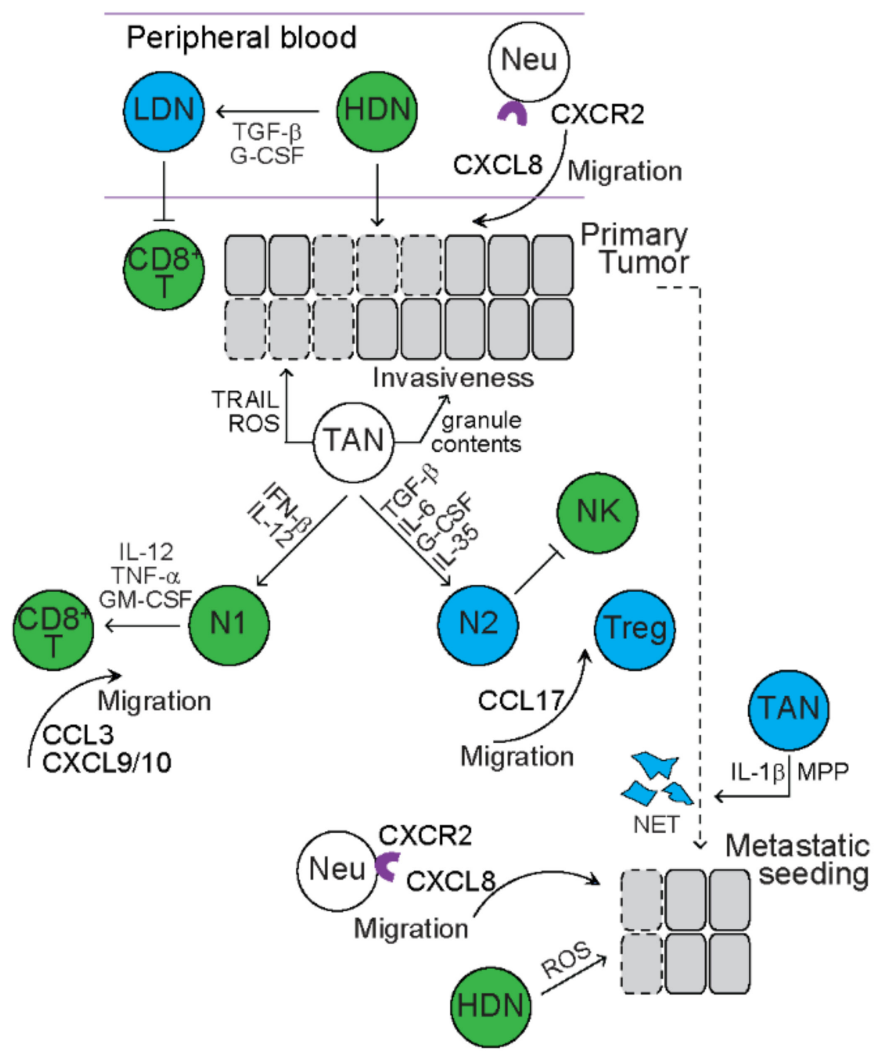

Figure 4. The function of neutrophils in tumors. Dark green circles represent mouse immune cells with anti-tumor function. Dark blue circles represent mouse immune cells with pro-tumor function. White circles represent mouse immune cells with both anti-tumor and pro-tumor function. Cells with dashed lines represent dead cells. Transforming growth factor beta (TGF- $\beta$ ) and granulocyte colony stimulating factor (G-CSF) induce transition of high-density neutrophils (HDN) to low density neutrophils (LDN) with tumor progression. HDN induce cytotoxicity of primary tumor cells and after metastasis, while LDN limit the proliferation of $\mathrm{CD}^{+} \mathrm{T}$ cells. C-X-C motif chemokine receptor 2 (CXCR2)/C-X-C chemokine ligand 8 (CXCL8) axis mediates recruitment of neutrophils (Neu) to primary and metastatic tumors. Tumor-associated neutrophils (TAN) promote invasiveness of cancer cells through releasing granule contents, promote dissemination of cancer cells by secreting interleukin 1 beta (IL-1 $\beta$ ) and matrix metalloproteinases (MPP). Neutrophil extracellular traps (NET) promote metastasis through catching cancer cells. TAN mediate cytotoxicity of tumor cells through producing tumor necrosis factor-related apoptosis-inducing ligand (TRAIL) and reactive oxygen species (ROS). TANs are polarized to anti-tumor N1 TANs (N1) or pro-tumor N2 TANs (N2) depending on TME cues. N1 TANs inhibit natural killer (NK) cell function while recruit regulatory $\mathrm{T}$ cells (Treg) to TME. N1 TAN secrete chemokines to recruit CD8 ${ }^{+} \mathrm{T}$ cells to TME and secrete cytokines to activate $\mathrm{CD}^{+}$T cells. IFN- $\beta$ : interferon beta; IL-12: interleukin 12; IL-6: interleukin 6; IL-35: interleukin 35; TNF- $\alpha$ : tumor necrosis factor alpha; GM-CSF: granulocyte-macrophage colony stimulating factor; CCL3: C-C motif chemokine ligand 3; CXCL9/10: C-X-C chemokine ligand 9/10; CCL17: C-C motif chemokine ligand 17. 


\section{Myeloid-Derived Suppressor Cells (MDSCs)}

\subsection{Function of MDSCs in Tumors}

MDSCs are a heterogenous group of myeloid progenitors and immature myeloid cells at distinct developmental stages that circulate the blood vessels [146]. In response to infection, MDSCs rapidly expand and differentiate into granulocytes, monocytes, macrophages, and DCs and play an essential role in the regulation of immune responses and tissue repair [146]. Human MDSCs express CD14 ${ }^{-}, \mathrm{CD}_{11 b^{+}}, \mathrm{CD}_{3}{ }^{+}$, and class II $\mathrm{MHC}^{-}$, while mouse MDSCs express CD11 $\mathrm{b}^{+}, \mathrm{Gr}-1^{+}$and the marker for immature myeloid cells CD $31^{+}[147$, 148]. In cancer patients, the number of circulating MDSCs increases and the infiltration of MDSCs in TME is associated with poor prognosis [149-151]. Tumor cells or TAMCs produce GM-CSF, G-CSF, and IL-6 that drive CCAAT/enhancer binding protein beta (C/EBP $\beta$ )-dependent myelopoiesis from myeloid progenitor cells in human and mouse bone marrow, generating MDSCs (Figure 5A) [152]. Mice bearing tumors that secrete IL-1 $\beta$ also induce myelopoiesis, leading to increased number of MDSCs in peripheral blood and spleens [153]. Deletion or blocking of prostaglandin E2 (PGE2) reduces the number of MDSCs via blocking differentiation of MDSCs from immature hematopoietic cells, indicating that PGE2 induces differentiation of MDSCs [154]. In a spontaneous melanoma mouse model, C-X-C motif chemokine ligand 5 (CXCL5) induces recruitment of CXCR2 ${ }^{+}$MDSCs to the primary tumor [155].

MDSCs exert various pro-tumor effects during tumor progression and metastasis (Figure 5A). Coculture of MDSCs with primary ovarian cancer cells increases the aldehyde dehydrogenase (ALDH) ${ }^{+}$cancer stem cells, promotes tumor sphere formation in vitro, and increases tumor incidences and metastatic foci in vivo in xengraft models, indicating that MDSCs enhance cancer stemness [151]. Mechanistic studies reveal that MDSCs upregulates the expression of microRNA101 that represses transcription factor C-terminal binding protein-2 (CtBP2), leading to upregulation of stem cell core genes, such as NANOG, OCT4/3, and SOX2 [151]. In tumor-bearing mice, transfer of MDSCs reduces apoptosis and necrosis of tumor cells, indicating that MDSCs provide pro-survival signals for tumor cells [156]. MDSCs accumulated in TME produce MMP9 to promote tumor growth and tumor vasculature [156]. These tumor-associated MDSCs acquire endothelial cell properties and incorporate into tumor vasculature [156]. MDSCs also secrete VEGF in a Stat3-dependent manner, which initiates angiogenesis through inducing endothelial cell migration and tube formation [157]. In melanoma-bearing mice, MDSC accumulated in TME produce TGF- $\beta$, EGF, and HGF to induce epithelial-mesenchymal transition (EMT), facilitating cancer cell dissemination [155].

The main feature of MDSCs is to suppress the function of immune cells with a focus on $\mathrm{T}$ cells (Figure 5A). Tumor-associated lineage ${ }^{-} \mathrm{CD} 45^{+} \mathrm{CD} 33^{+} \mathrm{MDSC}$ s from high-grade ovarian serous cancer patients suppress proliferation of $\mathrm{T}$ cells and inhibit their function through downregulating the expression of IL-2, INF- $\gamma$, and granzyme B, resulting in increased tumor volume [151]. MDSCs also reduce the number of antigen-specific CD8 ${ }^{+}$ $\mathrm{T}$ cells and inhibit the cytoxoticity of $\mathrm{CD}^{+} \mathrm{T}$ cells [152]. Mechanistic studies reveal that tumor-associated MDSCs in mice bearing lung carcinoma express high levels of arginase- 1 and cationic amino acid transporter 2B that deplete extracellular L-Arginine, leading to downregulated expression of CD3zeta and reduced proliferation of antigenspecific $\mathrm{T}$ cells [158]. Activation and proliferation of $\mathrm{T}$ cells requires importing of cysteine from APCs, such as macrophages and DCs [159]. MDSCs limit the cysteine supply of $\mathrm{T}$ cells by sequestering cysteine from extracellular space, leading to suppression of $\mathrm{T}$ cell expansion [159]. In tumor-bearing mice, MDSCs also disrupt the binding of T cell receptor (TCR) to MHC-antigen complex through nitration of TCR/CD8, leading to T cell anergy $[160,161]$. In colon carcinoma mouse model, MDSCs inhibit proliferation of CD4 ${ }^{+} \mathrm{T}$ cells driven by antigens, but induce the development of anergic and suppressive Tregs that is dependent on IL-10 and IFN- $\gamma$ [162]. 
A

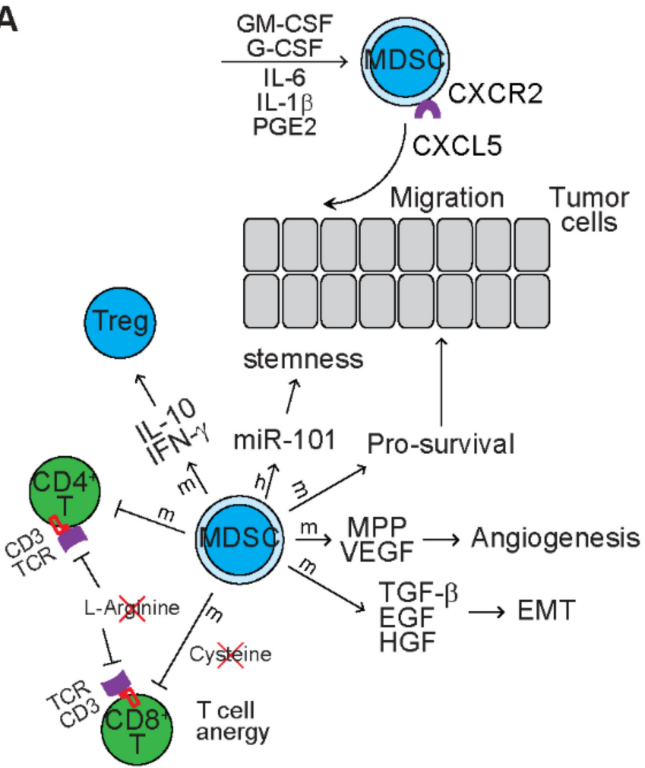

B

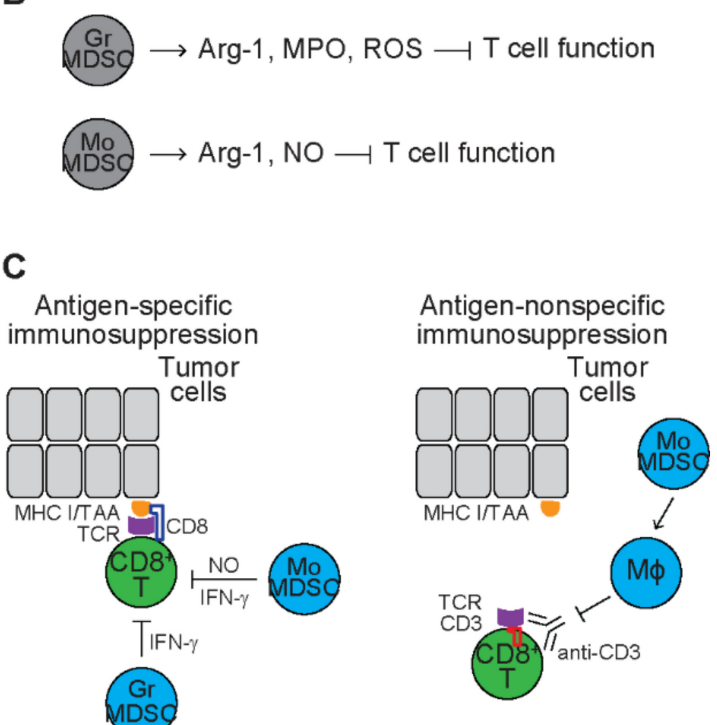

Figure 5. The function of MDSCs and MDSC subsets in tumors. (A) The function of MDSCs in tumors. Dark green circles represent mouse immune cells with anti-tumor function. Dark blue circles represent mouse immune cells with pro-tumor function. Light blue circles represent human immune cells with pro-tumor function. Various cytokines stimulate myelopoiesis, generating myeloid- derived suppressor cells (MDSC). The C-X-C chemokine ligand 5 (CXCL5)/ C-X-C motif chemokine receptor 2 (CXCR2) axis induces recruitment of circulating MDSC to tumor microenvironment (TME). MDSC enhance stemness and survival cancer cells. MDSC also stimulate angiogenesis and induce epithelial-mesenchymal transition (EMT). MDSC suppress proliferation and activation of T cells through depleting L-arginine and cysteine, downregulating CD3 and disrupting T-cell receptor (TCR) function. MDSC also induce regulatory T cells (Treg) through secreting interleukin 10 (IL-10) and interferon gamma (IFN- $\gamma$ ). GM-CSF: granulocyte-macrophage colony stimulating factor; G-CSF: granulocyte colony stimulating factor; IL-6: interleukin 6; IL-1 $\beta$ : interleukin 1 beta; PGE2: prostaglandin E2; MMP: matrix metalloproteinases; VEGF: vascular endothelial growth factor; TGF- $\beta$ : transforming growth factor beta; EGF: epidermal growth factor; HGF: hepatocyte growth factor; m: mouse; h: human. (B) MDSC subsets in tumorbearing mice. Granulocytic myeloid-derived suppressor cells (GrMDSC) suppress T cell function through producing reactive oxygen species (ROS). Monocytic myeloid-derived suppressor cells (MoMDSC) suppress T cell function through producing nitric oxide (NO). Arg-1: arginase-1; MPO: myeloperoxidase. (C) Immunosuppression mediated by MDSC subsets. GrMDSC mediate IFN- $\gamma$-dependent antigen-specific immunosuppression. MoMDSCs mediate antigen-specific immunosuppression that is required for IFN- $\gamma$ and NO (left panel). MoMDSC-derived macrophages (M $\phi)$ mediate antigen-nonspecific immunosuppression. MHC I: class I major histocompatibility complex; TAA: tumor-associated antigen.

\subsection{Subpopulations of Tumor-Associated MDSCs}

MDSCs consist of two main subpopulations (Figure 5B). Granulocytic MDSCs (GrMDSCs) are phenotypically and morphologically similar to neutrophils and express

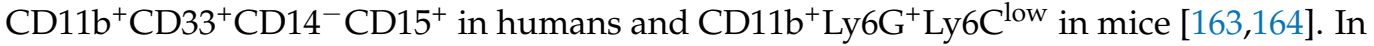
tumor-free mice, neutrophils exhibit high levels of phagocytosis and express high levels of lysosomal enzymes and TNF- $\alpha$ [165]. In tumor-bearing mice, GrMDSCs exhibit lower levels of phagocytosis but higher levels of activation or production of arginase-1, myeloperoxidase (MPO) and ROS that suppress T cell function [163-165]. For example, ROS reduce expression of TCR zeta chain and decrease cytokine production, leading to impaired T cell activation [166]. Monocytic MDSCs (MoMDSCs) are phenotypically and morphologically similar to monocytes and express CD14 ${ }^{+} \mathrm{HLA}_{-} \mathrm{DR}^{\text {low }}$ in humans and $\mathrm{CD}_{11 b^{+} \text {Ly6G }^{-} \text {Ly6C }}{ }^{\text {high }}$ in mice $[148,163,164]$. Compared to monocytes, MoMDSCs exhibit high levels of activation or production of arginase- 1 and $\mathrm{NO}$ and the ability to suppress $\mathrm{T}$ cell function $[163,164]$. NO impairs interleukin 2 (IL-2) downstream signaling pathways, including JAK3/STAT5, ERK, and AKT, leading to suppression of T cell activation and proliferation driven by antigens or mitogens [167]. 
Inoculation of T-cell lymphoma cells induces expansion of GrMDSCs and MoMDSCs in spleens of recipient mice [163]. Both GrMDSCs and MoMDSCs suppress proliferation of $\mathrm{CD} 8^{+} \mathrm{T}$ cells driven by ovalbumin protein, indicating antigen-specific immunosuppression (Figure 5C) [163]. Blocking of IFN- $\gamma$ completely reverses the suppressive effect of GrMDSCs on T cells but only partially reverses the suppressive effect of MoMDSCs on T cells, indicating that GrMDSCs mediate immunosuppression in an IFN- $\gamma$-dependent manner [163]. Inhibition of iNOS partly reverses the suppressive effect of MoMDSCs on T cells but shows no alteration on the suppressive effect of GrMDSCs on T cells, indicating that MoMDSCs supress $\mathrm{T}$ cell proliferation via the IFN- $\gamma$ and iNOS/NO pathways [163]. In addition, macrophages differentiated from MoMDSCs suppress proliferation of $\mathrm{CD}^{+} \mathrm{T}$ cells driven by anti-CD3 antibodies, indicating antigen-nonspecific immunosuppression [163]. Inhibition of iNOS completely reverses while blocking of IFN- $\gamma$ partially reverses suppressive effect of MoMDSC-derived macrophages on polyclonal T cell proliferation [163]. These studies suggest that both GrMDSCs and MoMDSCs contribute to the immunosuppression of $\mathrm{T}$ cells.

\section{Tumor-Associated Myeloid Cells in Cancer Therapy \\ 7.1. Chemotherapy}

Accumulating evidence reveal that TAMCs contribute to chemoresistance [168-170]. For example, TAMs release putrescine that protects colorectal cancer cells from 5-fluorouracil (5-FU)-mediated apoptosis [13]. In mice bearing lung carcinoma or breast cancer, M2 TAMs accumulate around TME vasculature after chemotherapy and release VEGF that promotes angiogenesis and relapse [14]. In response to paclitaxel, the anti-microtubule chemotherapeutic agent, macrophages infiltrate TME in mice bearing mammary tumors and secrete cathepsin to protect tumor cells from chemotherapy-mediated cell death [171]. Inhibition of cathepsin enhances the response to chemotherapy in tumor-bearing mice, leading to impaired tumor growth and metastasis in the recipient [171].

Therapeutic approaches targeting TAMCs as monotherapy or in combination with chemotherapy is being tested in preclinical and clinical settings. Among the heterogeneous population of TAMCs, TAMs, and MDSCs are mainly pro-tumoral and immunosuppressive, and are therefore being tested in different tumors. For example, targeting the recruitment of monocytes and TAMs to TME are being vigorously tested in animal models and patients with tumors. TAMs are recruited to TME by CSF- 1 and promote breast cancer development and metastasis [52]. Therefore, therapeutic approaches targeting the CSF-1/CSF-1R axis with $\mathrm{mAb}$ or small molecule compounds are being tested. In a mouse model bearing chemoresistant MCF-7 breast cancer cells, injection of a murinized antigen-binding fragment targeting mouse CSF-1 retards tumor growth, enhances response to chemotherapeutic agents-including cyclophosphamide, methotrexate, and 5-FU-and prolongs survival of the mice [172]. Humanized mAb (RG7155) suppressing human CSF-1R activation induces cell death of immunosuppressive M2-like macrophages in vitro [173]. In mice bearing colorectal adenocarcinoma and fibrosarcoma, treatment with chimeric mouse antibody suppressing mouse CSF-1R depletes TAMs, resulting in increased CD8/CD4 T cell ratio [173]. Treatment of RG7155 in seven patients diagnosed with diffuse-type giant cell tumor (DtGCT) results in partial clinical response in all patients and complete clinical response in two patients (clinicaltrials.gov identifier NCT01494688) [173]. In addition, the amount of $\mathrm{CD} 8^{+} \mathrm{CD} 163^{+}$macrophages is reduced in tumor biopsies from RG7155-treated Dt-GCT patients, indicating reduced recruitment of TAMs to TME [173]. In mice bearing glioblastoma multiforme or patient-derived glioma, BLZ945, a brain-penetrant kinase inhibitor targeting CSF-1R depolarizes M2 phenotype of TAMs, impairs their pro-tumor function and slows tumor growth that is associated with decreased M2 gene signatures [174]. In a glioma mouse model, a tyrosine kinase inhibitor PLX3397 that targets CSF-1R, c-Kit and Flt3 blocks tumor progression through depolarizing M2 phenotype of TAMs and impairing their pro-tumor function [175]. PLX3397 is also tested in patients with melanoma (clinicaltrials.gov identifier NCT02071940, NCT02975700), prostate cancer (clinicaltrials.gov 
identifier NCT01499043), and glioblastoma (clinicaltrials.gov identifier NCT01349036). Other CSF-1R inhibitors, such as ARRY-382 (clinicaltrials.gov NCT01316822), BLZ945 (clinicaltrials.gov identifier NCT02829723), AMG820 (clinicaltrials.gov identifier NCT01444404), and IMC-CS4 (clinicaltrials.gov identifier NCT01346358) are also tested in patients with various solid tumors.

In addition to monotherapy, inhibitors targeting CSF-1 or CSF-1R are also tested in combination with anti-cancer therapy for safety, tolerability and efficacy. For example, PLX3397 is tested in patients with advanced solid tumors in combination with paclitaxel (clinicaltrials.gov identifier NCT01525602) [176]. PLX3397 is tested in combination with eribulin in patients with breast cancer (clinicaltrials.gov identifier NCT01596751). PLX3397 is also tested with vemurafenib in patients with BRAF-mutated melanoma (clinicaltrials.gov identifier NCT01826448). PLX3397 is tested with sirolimus in patients advanced sarcomas (clinicaltrials.gov identifier NCT02584647). RG7155 is tested with paclitaxel in patients with ovarian cancers or breast cancers (clinicaltrials.gov identifier NCT01596751).

\subsection{Immunotherapy}

Upon binding to ligands CD80/CD86 expressed on APC and PD-L1 expressed on tumor cells, the immune checkpoint receptors, cytotoxic T-lymphocyte-associated protein 4 (CTLA-4) and PD-1, expressed on T cells induce inhibitory signals, leading to inactivation of T cells and immune evasion [177,178]. Inhibitors targeting CTLA- 4 and PD- 1 block these inhibitory pathways, leading to reactivation of anti-tumor immunity and clinical benefit in some cancer patients $[177,178]$. However, many cancer patients are resistant to immune checkpoint inhibitors $[177,178]$. Increasing studies suggest that TAMCs, such as MDSCs and TAMs, contribute to resistance to immune checkpoint inhibitors and therapeutic approaches targeting development, recruitment and function of MDSCs and TAMs are being tested for their ability to improve sensitivity to checkpoint inhibitors.

In melanoma patients, circulating $\mathrm{Lin}^{-} \mathrm{CD} 14^{+} \mathrm{HLA}-\mathrm{DR}{ }^{-}$moMDSCs are increased compared to healthy donors [179]. Melanoma patients responding to ipilimumab, an mAb targeting CTLA-4, exhibit less circulating moMDSCs than nonresponders [179]. Metastatic melanoma patients who fail to respond to ipilimumab are treated with nivolumab, an $\mathrm{mAb}$ targeting PD-1, and the frequency of circulating moMDSCs is inversely correlated to survival time [180]. In addition to circulating MDSCs, the accumulation of MDSCs in TME limits the clinical efficacy of checkpoint inhibitors in sarcoma patients [181]. In tumor-bearing mice, MDSCs infiltrated in TME express high levels of PD-L1 that is induced by HIF- $1 \alpha$ [182]. In sarcoma-bearing mice, sarcoma tissue induces expansion of MDSCs that express CXCR2 [181]. Deficiency or inhibition of CXCR2, the main chemokine receptor recruiting MDSCs to TME, reduces the infiltration of CD11b ${ }^{+}$Ly6G high MDSCs to TME, leading to enhanced anti-tumor effects upon treatment with checkpoint inhibitor [181]. In pancreatic cancer patients, the CXCR2 signaling is also overactivated [111]. In a pancreatic cancer mouse model, deletion or inhibition of CXCR2 enhances infiltration of T cells and extends survival time of mice that are treated with checkpoint inhibitors [111]. SX-682, a pharmacological inhibitor on CXCR1/2, inhibits infiltration of MDSCs to TME in oral and lung carcinoma mouse model, and enhances the effect of checkpoint inhibitors as well as T cell therapy [183]. Inhibition of CXCR2 is also tested in patients with pancreatic cancers (clinicaltrials.gov identifier NCT00851955) and metastatic melanoma (clinicaltrials.gov identifier NCT01740557). SC-682, the allosteric inhibitor of CXCR1/2, is tested in patients with myelodysplastic syndromes (clinicaltrials.gov identifier NCT04245397). SC-682 is also tested in combination with nivolumab in patients with metastatic pancreatic ductal adenocarcinoma (clinicaltrials.gov identifier NCT04477343). In addition, SC-682 is tested in combination with pembrolizumab, an $\mathrm{mAb}$ targeting $\mathrm{PD}-1$, in patients with metastatic melanoma (clinicaltrials.gov identifier NCT03161431).

In addition to targeting MDSCs, targeting recruitment of TAMs is also tested through inhibiting the CSF-1/CSF-1R axis in combination with checkpoint inhibitors. IMC-CS4 is tested in combination with PD-L1 inhibitor (durvalumab) or CTLA4 inhibitor (treme- 
limumab) in patients with solid tumors (clinicaltrials.gov identifier NCT02718911) [184]. PLX3397 is tested in combination with pembrolizumab in patients with various tumors (clinicaltrials.gov identifier NCT02452424). ARRY-382 is tested in combination with pembrolizumab in patients with solid tumors (clinicaltrials.gov identifier NCT02880371). BLZ945 is tested in combination with PDR001, an mAb targeting PD-1, in patients with solid tumors (clinicaltrials.gov identifier NCT02829723). RG7155 is tested in combination with atezolizumab, an $\mathrm{mAb}$ targeting PD-L1, in patients with various tumors (clinicaltrials.gov identifier NCT02323191). AMG820 is tested with pembrolizumab in patients with solid tumors (clinicaltrials.gov identifier NCT02713529).

\section{Conclusions}

Accumulating studies reveal that TAMCs play a critical role in tumor development, metastasis, immunomodulation, tumor vasculature formation, TME remodeling, and response to cancer therapy. Modulating the development, maturation and function of these myeloid cells merits the discovery of novel therapeutic strategies. However, these myeloid cells perform overlapping or opposing functions due to the complexity and plasticity of various interchangeable subpopulations. In addition, the molecular mechanism governing the behavior of TAMCs is largely unclear. Future studies will focus on further clarifying the function of each subpopulation of the myeloid cells in different cancers and identifying the molecular mechanism related to their pro-tumor and anti-tumor activities. This will help us understand the complexity of these myeloid cells and design novel targeted therapies.

Author Contributions: A.D. and J.F. wrote and edited the manuscript. Both authors have read and agreed to the published version of the manuscript.

Funding: This research was funded by This work was supported by NIH (R01CA218076), NIH COBRE 1P20GM109091-01, St. Baldrick's Foundation, Aplastic Anemia \& MDS International Foundation, NSF (1736150), and USC SOM IRF Endowment Fund.

Institutional Review Board Statement: Not applicable.

Informed Consent Statement: Not applicable.

Data Availability Statement: Not applicable.

Acknowledgments: We thank Tra Mi Phan and Isaac Park for editing and proofreading the manuscript.

Conflicts of Interest: The authors declare no conflict of interest.

\section{References}

1. Coussens, L.M.; Werb, Z. Inflammation and cancer. Nature 2002, 420, 860-867. [CrossRef]

2. Greten, F.R.; Grivennikov, S.I. Inflammation and Cancer: Triggers, Mechanisms, and Consequences. Immunity $2019,51,27-41$. [CrossRef]

3. Canli, O.; Nicolas, A.M.; Gupta, J.; Finkelmeier, F.; Goncharova, O.; Pesic, M.; Neumann, T.; Horst, D.; Lower, M.; Sahin, U.; et al. Myeloid Cell-Derived Reactive Oxygen Species Induce Epithelial Mutagenesis. Cancer Cell 2017, 32, 869-883. [CrossRef]

4. Zeng, X.Y.; Xie, H.; Yuan, J.; Jiang, X.Y.; Yong, J.H.; Zeng, D.; Dou, Y.Y.; Xiao, S.S. M2-like tumor-associated macrophages-secreted EGF promotes epithelial ovarian cancer metastasis via activating EGFR-ERK signaling and suppressing lncRNA LIMT expression. Cancer Biol. 2019, 20, 956-966. [CrossRef]

5. Wang, H.W.; Joyce, J.A. Alternative activation of tumor-associated macrophages by IL-4: Priming for protumoral functions. Cell Cycle 2010, 9, 4824-4835. [CrossRef] [PubMed]

6. Du, R.; Lu, K.V.; Petritsch, C.; Liu, P.; Ganss, R.; Passegue, E.; Song, H.; Vandenberg, S.; Johnson, R.S.; Werb, Z.; et al. HIF1alpha induces the recruitment of bone marrow-derived vascular modulatory cells to regulate tumor angiogenesis and invasion. Cancer Cell 2008, 13, 206-220. [CrossRef]

7. Madsen, D.H.; Jurgensen, H.J.; Siersbaek, M.S.; Kuczek, D.E.; Grey Cloud, L.; Liu, S.; Behrendt, N.; Grontved, L.; Weigert, R.; Bugge, T.H. Tumor-Associated Macrophages Derived from Circulating Inflammatory Monocytes Degrade Collagen through Cellular Uptake. Cell Rep. 2017, 21, 3662-3671. [CrossRef] [PubMed]

8. Lin, E.Y.; Pollard, J.W. Tumor-associated macrophages press the angiogenic switch in breast cancer. Cancer Res. 2007, 67, 5064-5066. [CrossRef] 
9. Munn, D.H.; Sharma, M.D.; Hou, D.; Baban, B.; Lee, J.R.; Antonia, S.J.; Messina, J.L.; Chandler, P.; Koni, P.A.; Mellor, A.L. Expression of indoleamine 2,3-dioxygenase by plasmacytoid dendritic cells in tumor-draining lymph nodes. J. Clin. Investig. 2004, 114, 280-290. [CrossRef] [PubMed]

10. Castellaneta, A.; Sumpter, T.L.; Chen, L.; Tokita, D.; Thomson, A.W. NOD2 ligation subverts IFN-alpha production by liver plasmacytoid dendritic cells and inhibits their T cell allostimulatory activity via B7-H1 up-regulation. J. Immunol. 2009, 183, 6922-6932. [CrossRef] [PubMed]

11. Labidi-Galy, S.I.; Sisirak, V.; Meeus, P.; Gobert, M.; Treilleux, I.; Bajard, A.; Combes, J.D.; Faget, J.; Mithieux, F.; Cassignol, A.; et al. Quantitative and functional alterations of plasmacytoid dendritic cells contribute to immune tolerance in ovarian cancer. Cancer Res. 2011, 71, 5423-5434. [CrossRef] [PubMed]

12. Prima, V.; Kaliberova, L.N.; Kaliberov, S.; Curiel, D.T.; Kusmartsev, S. COX2/mPGES1/PGE2 pathway regulates PD-L1 expression in tumor-associated macrophages and myeloid-derived suppressor cells. Proc. Natl. Acad. Sci. USA 2017, 114, 1117-1122. [CrossRef]

13. Zhang, X.; Chen, Y.; Hao, L.; Hou, A.; Chen, X.; Li, Y.; Wang, R.; Luo, P.; Ruan, Z.; Ou, J.; et al. Macrophages induce resistance to 5-fluorouracil chemotherapy in colorectal cancer through the release of putrescine. Cancer Lett. 2016, 381, 305-313. [CrossRef]

14. Hughes, R.; Qian, B.Z.; Rowan, C.; Muthana, M.; Keklikoglou, I.; Olson, O.C.; Tazzyman, S.; Danson, S.; Addison, C.; Clemons, M.; et al. Perivascular M2 Macrophages Stimulate Tumor Relapse after Chemotherapy. Cancer Res. 2015, 75, 3479-3491. [CrossRef] [PubMed]

15. Qian, B.Z.; Li, J.; Zhang, H.; Kitamura, T.; Zhang, J.; Campion, L.R.; Kaiser, E.A.; Snyder, L.A.; Pollard, J.W. CCL2 recruits inflammatory monocytes to facilitate breast-tumour metastasis. Nature 2011, 475, 222-225. [CrossRef]

16. Gong, D.; Shi, W.; Yi, S.J.; Chen, H.; Groffen, J.; Heisterkamp, N. TGFbeta signaling plays a critical role in promoting alternative macrophage activation. BMC Immunol. 2012, 13, 31. [CrossRef] [PubMed]

17. Colegio, O.R.; Chu, N.Q.; Szabo, A.L.; Chu, T.; Rhebergen, A.M.; Jairam, V.; Cyrus, N.; Brokowski, C.E.; Eisenbarth, S.C.; Phillips, G.M.; et al. Functional polarization of tumour-associated macrophages by tumour-derived lactic acid. Nature 2014, 513, 559-563. [CrossRef]

18. Ziegler-Heitbrock, L.; Ancuta, P.; Crowe, S.; Dalod, M.; Grau, V.; Hart, D.N.; Leenen, P.J.; Liu, Y.J.; MacPherson, G.; Randolph, G.J.; et al. Nomenclature of monocytes and dendritic cells in blood. Blood 2010, 116, e74-e80. [CrossRef]

19. Hettinger, J.; Richards, D.M.; Hansson, J.; Barra, M.M.; Joschko, A.C.; Krijgsveld, J.; Feuerer, M. Origin of monocytes and macrophages in a committed progenitor. Nat. Immunol. 2013, 14, 821-830. [CrossRef]

20. Kawamura, S.; Onai, N.; Miya, F.; Sato, T.; Tsunoda, T.; Kurabayashi, K.; Yotsumoto, S.; Kuroda, S.; Takenaka, K.; Akashi, K.; et al. Identification of a Human Clonogenic Progenitor with Strict Monocyte Differentiation Potential: A Counterpart of Mouse cMoPs. Immunity 2017, 46, 835-848. [CrossRef] [PubMed]

21. Serbina, N.V.; Pamer, E.G. Monocyte emigration from bone marrow during bacterial infection requires signals mediated by chemokine receptor CCR2. Nat. Immunol. 2006, 7, 311-317. [CrossRef]

22. Jakubzick, C.; Gautier, E.L.; Gibbings, S.L.; Sojka, D.K.; Schlitzer, A.; Johnson, T.E.; Ivanov, S.; Duan, Q.; Bala, S.; Condon, T.; et al. Minimal differentiation of classical monocytes as they survey steady-state tissues and transport antigen to lymph nodes. Immunity 2013, 39, 599-610. [CrossRef]

23. Sunderkotter, C.; Nikolic, T.; Dillon, M.J.; Van Rooijen, N.; Stehling, M.; Drevets, D.A.; Leenen, P.J. Subpopulations of mouse blood monocytes differ in maturation stage and inflammatory response. J. Immunol. 2004, 172, 4410-4417. [CrossRef]

24. Yona, S.; Kim, K.W.; Wolf, Y.; Mildner, A.; Varol, D.; Breker, M.; Strauss-Ayali, D.; Viukov, S.; Guilliams, M.; Misharin, A.; et al. Fate mapping reveals origins and dynamics of monocytes and tissue macrophages under homeostasis. Immunity 2013, 38, 79-91. [CrossRef] [PubMed]

25. Jakubzick, C.V.; Randolph, G.J.; Henson, P.M. Monocyte differentiation and antigen-presenting functions. Nat. Rev. Immunol. 2017, 17, 349-362. [CrossRef] [PubMed]

26. Griffith, T.S.; Wiley, S.R.; Kubin, M.Z.; Sedger, L.M.; Maliszewski, C.R.; Fanger, N.A. Monocyte-mediated tumoricidal activity via the tumor necrosis factor-related cytokine, TRAIL. J. Exp. Med. 1999, 189, 1343-1354. [CrossRef] [PubMed]

27. Szaflarska, A.; Baj-Krzyworzeka, M.; Siedlar, M.; Weglarczyk, K.; Ruggiero, I.; Hajto, B.; Zembala, M. Antitumor response of CD14+/CD16+ monocyte subpopulation. Exp. Hematol. 2004, 32, 748-755. [CrossRef]

28. Munn, D.H.; Cheung, N.K. Phagocytosis of tumor cells by human monocytes cultured in recombinant macrophage colonystimulating factor. J. Exp. Med. 1990, 172, 231-237. [CrossRef]

29. Yeap, W.H.; Wong, K.L.; Shimasaki, N.; Teo, E.C.; Quek, J.K.; Yong, H.X.; Diong, C.P.; Bertoletti, A.; Linn, Y.C.; Wong, S.C. CD16 is indispensable for antibody-dependent cellular cytotoxicity by human monocytes. Sci. Rep. 2016, 6, 34310. [CrossRef]

30. Romano, E.; Kusio-Kobialka, M.; Foukas, P.G.; Baumgaertner, P.; Meyer, C.; Ballabeni, P.; Michielin, O.; Weide, B.; Romero, P.; Speiser, D.E. Ipilimumab-dependent cell-mediated cytotoxicity of regulatory T cells ex vivo by nonclassical monocytes in melanoma patients. Proc. Natl. Acad. Sci. USA 2015, 112, 6140-6145. [CrossRef]

31. Chittezhath, M.; Dhillon, M.K.; Lim, J.Y.; Laoui, D.; Shalova, I.N.; Teo, Y.L.; Chen, J.; Kamaraj, R.; Raman, L.; Lum, J.; et al. Molecular profiling reveals a tumor-promoting phenotype of monocytes and macrophages in human cancer progression. Immunity 2014, 41, 815-829. [CrossRef]

32. Headley, M.B.; Bins, A.; Nip, A.; Roberts, E.W.; Looney, M.R.; Gerard, A.; Krummel, M.F. Visualization of immediate immune responses to pioneer metastatic cells in the lung. Nature 2016, 531, 513-517. [CrossRef] 
33. Hanna, R.N.; Cekic, C.; Sag, D.; Tacke, R.; Thomas, G.D.; Nowyhed, H.; Herrley, E.; Rasquinha, N.; McArdle, S.; Wu, R.; et al. Patrolling monocytes control tumor metastasis to the lung. Science 2015, 350, 985-990. [CrossRef]

34. Hume, D.A. The mononuclear phagocyte system. Curr. Opin. Immunol. 2006, 18, 49-53. [CrossRef]

35. Ginhoux, F.; Guilliams, M. Tissue-Resident Macrophage Ontogeny and Homeostasis. Immunity 2016, 44, 439-449. [CrossRef] [PubMed]

36. Martin, P.; D'Souza, D.; Martin, J.; Grose, R.; Cooper, L.; Maki, R.; McKercher, S.R. Wound healing in the PU.1 null mouse-tissue repair is not dependent on inflammatory cells. Curr. Biol. 2003, 13, 1122-1128. [CrossRef]

37. Petty, A.J.; Yang, Y. Tumor-Associated Macrophages in Hematologic Malignancies: New Insights and Targeted Therapies. Cells 2019, 8, 1526. [CrossRef] [PubMed]

38. Jablonski, K.A.; Amici, S.A.; Webb, L.M.; Ruiz-Rosado Jde, D.; Popovich, P.G.; Partida-Sanchez, S.; Guerau-de-Arellano, M. Novel Markers to Delineate Murine M1 and M2 Macrophages. PLoS ONE 2015, 10, e0145342. [CrossRef]

39. Orecchioni, M.; Ghosheh, Y.; Pramod, A.B.; Ley, K. Macrophage Polarization: Different Gene Signatures in M1(LPS+) vs. Classically and M2(LPS-) vs. Alternatively Activated Macrophages. Front Immunol. 2019, 10, 1084. [CrossRef] [PubMed]

40. Sica, A.; Mantovani, A. Macrophage plasticity and polarization: In vivo veritas. J. Clin. Investig. 2012, 122, 787-795. [CrossRef]

41. Kigerl, K.A.; Gensel, J.C.; Ankeny, D.P.; Alexander, J.K.; Donnelly, D.J.; Popovich, P.G. Identification of two distinct macrophage subsets with divergent effects causing either neurotoxicity or regeneration in the injured mouse spinal cord. J. Neurosci. 2009, 29, 13435-13444. [CrossRef] [PubMed]

42. Stein, M.; Keshav, S.; Harris, N.; Gordon, S. Interleukin 4 potently enhances murine macrophage mannose receptor activity: A marker of alternative immunologic macrophage activation. J. Exp. Med. 1992, 176, 287-292. [CrossRef] [PubMed]

43. Martinez, F.O.; Helming, L.; Gordon, S. Alternative activation of macrophages: An immunologic functional perspective. Annu. Rev. Immunol. 2009, 27, 451-483. [CrossRef] [PubMed]

44. Tarique, A.A.; Logan, J.; Thomas, E.; Holt, P.G.; Sly, P.D.; Fantino, E. Phenotypic, functional, and plasticity features of classical and alternatively activated human macrophages. Am. J. Respir. Cell Mol. Biol. 2015, 53, 676-688. [CrossRef] [PubMed]

45. Vijayan, V.; Pradhan, P.; Braud, L.; Fuchs, H.R.; Gueler, F.; Motterlini, R.; Foresti, R.; Immenschuh, S. Human and murine macrophages exhibit differential metabolic responses to lipopolysaccharide-A divergent role for glycolysis. Redox Biol. 2019, 22, 101147. [CrossRef] [PubMed]

46. Martinez, F.O.; Helming, L.; Milde, R.; Varin, A.; Melgert, B.N.; Draijer, C.; Thomas, B.; Fabbri, M.; Crawshaw, A.; Ho, L.P.; et al. Genetic programs expressed in resting and IL-4 alternatively activated mouse and human macrophages: Similarities and differences. Blood 2013, 121, e57-e69. [CrossRef] [PubMed]

47. Yuan, Z.Y.; Luo, R.Z.; Peng, R.J.; Wang, S.S.; Xue, C. High infiltration of tumor-associated macrophages in triple-negative breast cancer is associated with a higher risk of distant metastasis. Onco Targets 2014, 7, 1475-1480. [CrossRef] [PubMed]

48. Al-Matary, Y.S.; Botezatu, L.; Opalka, B.; Hones, J.M.; Lams, R.F.; Thivakaran, A.; Schutte, J.; Koster, R.; Lennartz, K.; Schroeder, T.; et al. Acute myeloid leukemia cells polarize macrophages towards a leukemia supporting state in a Growth factor independence 1 dependent manner. Haematologica 2016, 101, 1216-1227. [CrossRef]

49. Beider, K.; Bitner, H.; Leiba, M.; Gutwein, O.; Koren-Michowitz, M.; Ostrovsky, O.; Abraham, M.; Wald, H.; Galun, E.; Peled, A.; et al. Multiple myeloma cells recruit tumor-supportive macrophages through the CXCR4/CXCL12 axis and promote their polarization toward the M2 phenotype. Oncotarget 2014, 5, 11283-11296. [CrossRef]

50. Komohara, Y.; Niino, D.; Saito, Y.; Ohnishi, K.; Horlad, H.; Ohshima, K.; Takeya, M. Clinical significance of CD163(+) tumorassociated macrophages in patients with adult T-cell leukemia/lymphoma. Cancer Sci. 2013, 104, 945-951. [CrossRef] [PubMed]

51. Ma, J.; Liu, L.; Che, G.; Yu, N.; Dai, F.; You, Z. The M1 form of tumor-associated macrophages in non-small cell lung cancer is positively associated with survival time. BMC Cancer 2010, 10, 112. [CrossRef]

52. Lin, E.Y.; Nguyen, A.V.; Russell, R.G.; Pollard, J.W. Colony-stimulating factor 1 promotes progression of mammary tumors to malignancy. J. Exp. Med. 2001, 193, 727-740. [CrossRef]

53. Zhu, Y.; Herndon, J.M.; Sojka, D.K.; Kim, K.W.; Knolhoff, B.L.; Zuo, C.; Cullinan, D.R.; Luo, J.; Bearden, A.R.; Lavine, K.J.; et al. Tissue-Resident Macrophages in Pancreatic Ductal Adenocarcinoma Originate from Embryonic Hematopoiesis and Promote Tumor Progression. Immunity 2017, 47, 323-338. [CrossRef]

54. Noy, R.; Pollard, J.W. Tumor-associated macrophages: From mechanisms to therapy. Immunity 2014, 41, 49-61. [CrossRef] [PubMed]

55. Lawrence, T.; Natoli, G. Transcriptional regulation of macrophage polarization: Enabling diversity with identity. Nat. Rev. Immunol. 2011, 11, 750-761. [CrossRef]

56. Hanna, A.; Metge, B.J.; Bailey, S.K.; Chen, D.; Chandrashekar, D.S.; Varambally, S.; Samant, R.S.; Shevde, L.A. Inhibition of Hedgehog signaling reprograms the dysfunctional immune microenvironment in breast cancer. Oncoimmunology $2019,8,1548241$. [CrossRef] [PubMed]

57. Yang, X.; Feng, W.; Wang, R.; Yang, F.; Wang, L.; Chen, S.; Ru, Y.; Cheng, T.; Zheng, G. Repolarizing heterogeneous leukemiaassociated macrophages with more M1 characteristics eliminates their pro-leukemic effects. Oncoimmunology 2018,7 , e1412910. [CrossRef] [PubMed]

58. Moore, R.J.; Owens, D.M.; Stamp, G.; Arnott, C.; Burke, F.; East, N.; Holdsworth, H.; Turner, L.; Rollins, B.; Pasparakis, M.; et al. Mice deficient in tumor necrosis factor-alpha are resistant to skin carcinogenesis. Nat. Med. 1999, 5, 828-831. [CrossRef] [PubMed] 
59. Sumitomo, R.; Hirai, T.; Fujita, M.; Murakami, H.; Otake, Y.; Huang, C.L. PD-L1 expression on tumor-infiltrating immune cells is highly associated with M2 TAM and aggressive malignant potential in patients with resected non-small cell lung cancer. Lung Cancer 2019, 136, 136-144. [CrossRef] [PubMed]

60. Loeuillard, E.; Yang, J.; Buckarma, E.; Wang, J.; Liu, Y.; Conboy, C.; Pavelko, K.D.; Li, Y.; O'Brien, D.; Wang, C.; et al. Targeting tumor-associated macrophages and granulocytic myeloid-derived suppressor cells augments PD-1 blockade in cholangiocarcinoma. J. Clin. Investig. 2020, 130, 5380-5396. [CrossRef] [PubMed]

61. Pollari, M.; Bruck, O.; Pellinen, T.; Vahamurto, P.; Karjalainen-Lindsberg, M.L.; Mannisto, S.; Kallioniemi, O.; KellokumpuLehtinen, P.L.; Mustjoki, S.; Leivonen, S.K.; et al. PD-L1(+) tumor-associated macrophages and PD-1(+) tumor-infiltrating lymphocytes predict survival in primary testicular lymphoma. Haematologica 2018, 103, 1908-1914. [CrossRef]

62. Shan, T.; Chen, S.; Chen, X.; Wu, T.; Yang, Y.; Li, S.; Ma, J.; Zhao, J.; Lin, W.; Li, W.; et al. M2TAM subsets altered by lactic acid promote Tcell apoptosis through the PDL1/PD1 pathway. Oncol. Rep. 2020, 44, 1885-1894. [CrossRef]

63. Ramos, R.N.; Rodriguez, C.; Hubert, M.; Ardin, M.; Treilleux, I.; Ries, C.H.; Lavergne, E.; Chabaud, S.; Colombe, A.; Tredan, O.; et al. CD163(+) tumor-associated macrophage accumulation in breast cancer patients reflects both local differentiation signals and systemic skewing of monocytes. Clin. Transl. Immunol. 2020, 9, e1108. [CrossRef]

64. Curiel, T.J.; Coukos, G.; Zou, L.; Alvarez, X.; Cheng, P.; Mottram, P.; Evdemon-Hogan, M.; Conejo-Garcia, J.R.; Zhang, L.; Burow, M.; et al. Specific recruitment of regulatory $\mathrm{T}$ cells in ovarian carcinoma fosters immune privilege and predicts reduced survival. Nat. Med. 2004, 10, 942-949. [CrossRef] [PubMed]

65. Liu, J.; Zhang, N.; Li, Q.; Zhang, W.; Ke, F.; Leng, Q.; Wang, H.; Chen, J.; Wang, H. Tumor-associated macrophages recruit CCR6+ regulatory $\mathrm{T}$ cells and promote the development of colorectal cancer via enhancing CCL20 production in mice. PLoS ONE 2011, 6, e19495. [CrossRef]

66. Schmidt, A.; Zhang, X.M.; Joshi, R.N.; Iqbal, S.; Wahlund, C.; Gabrielsson, S.; Harris, R.A.; Tegner, J. Human macrophages induce CD4(+)Foxp3(+) regulatory T cells via binding and re-release of TGF-beta. Immunol. Cell Biol. 2016, 94, 747-762. [CrossRef]

67. Sharda, D.R.; Yu, S.; Ray, M.; Squadrito, M.L.; De Palma, M.; Wynn, T.A.; Morris, S.M., Jr.; Hankey, P.A. Regulation of macrophage arginase expression and tumor growth by the Ron receptor tyrosine kinase. J. Immunol. 2011, 187, 2181-2192. [CrossRef] [PubMed]

68. Zajac, E.; Schweighofer, B.; Kupriyanova, T.A.; Juncker-Jensen, A.; Minder, P.; Quigley, J.P.; Deryugina, E.I. Angiogenic capacity of M1- and M2-polarized macrophages is determined by the levels of TIMP-1 complexed with their secreted proMMP-9. Blood 2013, 122, 4054-4067. [CrossRef] [PubMed]

69. Afik, R.; Zigmond, E.; Vugman, M.; Klepfish, M.; Shimshoni, E.; Pasmanik-Chor, M.; Shenoy, A.; Bassat, E.; Halpern, Z.; Geiger, T.; et al. Tumor macrophages are pivotal constructors of tumor collagenous matrix. J. Exp. Med. 2016, 213, 2315-2331. [CrossRef]

70. Wu, L.; Liu, Y.J. Development of dendritic-cell lineages. Immunity 2007, 26, 741-750. [CrossRef]

71. Laoui, D.; Keirsse, J.; Morias, Y.; Van Overmeire, E.; Geeraerts, X.; Elkrim, Y.; Kiss, M.; Bolli, E.; Lahmar, Q.; Sichien, D.; et al. The tumour microenvironment harbours ontogenically distinct dendritic cell populations with opposing effects on tumour immunity. Nat. Commun. 2016, 7, 13720. [CrossRef]

72. Broz, M.L.; Binnewies, M.; Boldajipour, B.; Nelson, A.E.; Pollack, J.L.; Erle, D.J.; Barczak, A.; Rosenblum, M.D.; Daud, A.; Barber, D.L.; et al. Dissecting the tumor myeloid compartment reveals rare activating antigen-presenting cells critical for $\mathrm{T}$ cell immunity. Cancer Cell 2014, 26, 638-652. [CrossRef] [PubMed]

73. Truxova, I.; Kasikova, L.; Hensler, M.; Skapa, P.; Laco, J.; Pecen, L.; Belicova, L.; Praznovec, I.; Halaska, M.J.; Brtnicky, T.; et al. Mature dendritic cells correlate with favorable immune infiltrate and improved prognosis in ovarian carcinoma patients. J. Immunother. Cancer 2018, 6, 139. [CrossRef]

74. Michea, P.; Noel, F.; Zakine, E.; Czerwinska, U.; Sirven, P.; Abouzid, O.; Goudot, C.; Scholer-Dahirel, A.; Vincent-Salomon, A.; Reyal, F; et al. Adjustment of dendritic cells to the breast-cancer microenvironment is subset specific. Nat. Immunol. 2018, 19, 885-897. [CrossRef] [PubMed]

75. Scarlett, U.K.; Rutkowski, M.R.; Rauwerdink, A.M.; Fields, J.; Escovar-Fadul, X.; Baird, J.; Cubillos-Ruiz, J.R.; Jacobs, A.C.; Gonzalez, J.L.; Weaver, J.; et al. Ovarian cancer progression is controlled by phenotypic changes in dendritic cells. J. Exp. Med. 2012, 209, 495-506. [CrossRef]

76. Verneau, J.; Sautes-Fridman, C.; Sun, C.M. Dendritic cells in the tumor microenvironment: Prognostic and theranostic impact. Semin. Immunol. 2020, 48, 101410. [CrossRef]

77. Jongbloed, S.L.; Kassianos, A.J.; McDonald, K.J.; Clark, G.J.; Ju, X.; Angel, C.E.; Chen, C.J.; Dunbar, P.R.; Wadley, R.B.; Jeet, V.; et al. Human CD141+ (BDCA-3)+ dendritic cells (DCs) represent a unique myeloid DC subset that cross-presents necrotic cell antigens. J. Exp. Med. 2010, 207, 1247-1260. [CrossRef] [PubMed]

78. Melaiu, O.; Chierici, M.; Lucarini, V.; Jurman, G.; Conti, L.A.; De Vito, R.; Boldrini, R.; Cifaldi, L.; Castellano, A.; Furlanello, C.; et al. Cellular and gene signatures of tumor-infiltrating dendritic cells and natural-killer cells predict prognosis of neuroblastoma. Nat. Commun. 2020, 11, 5992. [CrossRef]

79. Bottcher, J.P.; Bonavita, E.; Chakravarty, P.; Blees, H.; Cabeza-Cabrerizo, M.; Sammicheli, S.; Rogers, N.C.; Sahai, E.; Zelenay, S.; Reis e Sousa, C. NK Cells Stimulate Recruitment of cDC1 into the Tumor Microenvironment Promoting Cancer Immune Control. Cell 2018, 172, 1022-1037. [CrossRef]

80. Spranger, S.; Dai, D.; Horton, B.; Gajewski, T.F. Tumor-Residing Batf3 Dendritic Cells Are Required for Effector T Cell Trafficking and Adoptive T Cell Therapy. Cancer Cell 2017, 31, 711-723. [CrossRef] 
81. Haniffa, M.; Shin, A.; Bigley, V.; McGovern, N.; Teo, P.; See, P.; Wasan, P.S.; Wang, X.N.; Malinarich, F.; Malleret, B.; et al. Human tissues contain CD141hi cross-presenting dendritic cells with functional homology to mouse CD103+ nonlymphoid dendritic cells. Immunity 2012, 37, 60-73. [CrossRef] [PubMed]

82. Roberts, E.W.; Broz, M.L.; Binnewies, M.; Headley, M.B.; Nelson, A.E.; Wolf, D.M.; Kaisho, T.; Bogunovic, D.; Bhardwaj, N.; Krummel, M.F. Critical Role for CD103(+)/CD141(+) Dendritic Cells Bearing CCR7 for Tumor Antigen Trafficking and Priming of T Cell Immunity in Melanoma. Cancer Cell 2016, 30, 324-336. [CrossRef]

83. Salmon, H.; Idoyaga, J.; Rahman, A.; Leboeuf, M.; Remark, R.; Jordan, S.; Casanova-Acebes, M.; Khudoynazarova, M.; Agudo, J.; Tung, N.; et al. Expansion and Activation of CD103(+) Dendritic Cell Progenitors at the Tumor Site Enhances Tumor Responses to Therapeutic PD-L1 and BRAF Inhibition. Immunity 2016, 44, 924-938. [CrossRef] [PubMed]

84. Balan, S.; Saxena, M.; Bhardwaj, N. Dendritic cell subsets and locations. Int. Rev. Cell Mol. Biol. 2019, 348, 1-68. [CrossRef]

85. Leal Rojas, I.M.; Mok, W.H.; Pearson, F.E.; Minoda, Y.; Kenna, T.J.; Barnard, R.T.; Radford, K.J. Human Blood CD1c(+) Dendritic Cells Promote Th1 and Th17 Effector Function in Memory CD4(+) T Cells. Front Immunol. 2017, 8, 971. [CrossRef]

86. Binnewies, M.; Mujal, A.M.; Pollack, J.L.; Combes, A.J.; Hardison, E.A.; Barry, K.C.; Tsui, J.; Ruhland, M.K.; Kersten, K.; Abushawish, M.A.; et al. Unleashing Type-2 Dendritic Cells to Drive Protective Antitumor CD4(+) T Cell Immunity. Cell 2019, 177, 556-571. [CrossRef] [PubMed]

87. Gerner, M.Y.; Casey, K.A.; Kastenmuller, W.; Germain, R.N. Dendritic cell and antigen dispersal landscapes regulate T cell immunity. J. Exp. Med. 2017, 214, 3105-3122. [CrossRef]

88. Borst, J.; Ahrends, T.; Babala, N.; Melief, C.J.M.; Kastenmuller, W. CD4(+) T cell help in cancer immunology and immunotherapy. Nat. Rev. Immunol. 2018, 18, 635-647. [CrossRef] [PubMed]

89. Zilionis, R.; Engblom, C.; Pfirschke, C.; Savova, V.; Zemmour, D.; Saatcioglu, H.D.; Krishnan, I.; Maroni, G.; Meyerovitz, C.V.; Kerwin, C.M.; et al. Single-Cell Transcriptomics of Human and Mouse Lung Cancers Reveals Conserved Myeloid Populations across Individuals and Species. Immunity 2019, 50, 1317-1334. [CrossRef] [PubMed]

90. Cella, M.; Jarrossay, D.; Facchetti, F.; Alebardi, O.; Nakajima, H.; Lanzavecchia, A.; Colonna, M. Plasmacytoid monocytes migrate to inflamed lymph nodes and produce large amounts of type I interferon. Nat. Med. 1999, 5, 919-923. [CrossRef]

91. Labidi-Galy, S.I.; Treilleux, I.; Goddard-Leon, S.; Combes, J.D.; Blay, J.Y.; Ray-Coquard, I.; Caux, C.; Bendriss-Vermare, N. Plasmacytoid dendritic cells infiltrating ovarian cancer are associated with poor prognosis. Oncoimmunology 2012, 1, 380-382. [CrossRef]

92. Aspord, C.; Leccia, M.T.; Charles, J.; Plumas, J. Plasmacytoid dendritic cells support melanoma progression by promoting Th2 and regulatory immunity through OX40L and ICOSL. Cancer Immunol. Res. 2013, 1, 402-415. [CrossRef] [PubMed]

93. Sisirak, V.; Faget, J.; Gobert, M.; Goutagny, N.; Vey, N.; Treilleux, I.; Renaudineau, S.; Poyet, G.; Labidi-Galy, S.I.; Goddard-Leon, S.; et al. Impaired IFN-alpha production by plasmacytoid dendritic cells favors regulatory T-cell expansion that may contribute to breast cancer progression. Cancer Res. 2012, 72, 5188-5197. [CrossRef]

94. Hartmann, E.; Wollenberg, B.; Rothenfusser, S.; Wagner, M.; Wellisch, D.; Mack, B.; Giese, T.; Gires, O.; Endres, S.; Hartmann, G. Identification and functional analysis of tumor-infiltrating plasmacytoid dendritic cells in head and neck cancer. Cancer Res. 2003, 63, 6478-6487.

95. Salio, M.; Cella, M.; Vermi, W.; Facchetti, F.; Palmowski, M.J.; Smith, C.L.; Shepherd, D.; Colonna, M.; Cerundolo, V. Plasmacytoid dendritic cells prime IFN-gamma-secreting melanoma-specific CD8 lymphocytes and are found in primary melanoma lesions. Eur. J. Immunol. 2003, 33, 1052-1062. [CrossRef]

96. Liu, C.; Lou, Y.; Lizee, G.; Qin, H.; Liu, S.; Rabinovich, B.; Kim, G.J.; Wang, Y.H.; Ye, Y.; Sikora, A.G.; et al. Plasmacytoid dendritic cells induce NK cell-dependent, tumor antigen-specific T cell cross-priming and tumor regression in mice. J. Clin. Investig. 2008, 118, 1165-1175. [CrossRef] [PubMed]

97. Matsui, T.; Connolly, J.E.; Michnevitz, M.; Chaussabel, D.; Yu, C.I.; Glaser, C.; Tindle, S.; Pypaert, M.; Freitas, H.; Piqueras, B.; et al. CD2 distinguishes two subsets of human plasmacytoid dendritic cells with distinct phenotype and functions. J. Immunol. 2009, 182, 6815-6823. [CrossRef] [PubMed]

98. Segura, E.; Amigorena, S. Inflammatory dendritic cells in mice and humans. Trends Immunol. 2013, 34, 440-445. [CrossRef]

99. Segura, E.; Touzot, M.; Bohineust, A.; Cappuccio, A.; Chiocchia, G.; Hosmalin, A.; Dalod, M.; Soumelis, V.; Amigorena, S. Human inflammatory dendritic cells induce Th17 cell differentiation. Immunity 2013, 38, 336-348. [CrossRef]

100. Marigo, I.; Zilio, S.; Desantis, G.; Mlecnik, B.; Agnellini, A.H.; Ugel, S.; Sasso, M.S.; Qualls, J.E.; Kratochvill, F.; Zanovello, P.; et al. T Cell Cancer Therapy Requires CD40-CD40L Activation of Tumor Necrosis Factor and Inducible Nitric-Oxide-Synthase-Producing Dendritic Cells. Cancer Cell 2016, 30, 651. [CrossRef]

101. Zucker, A.; Winter, A.; Lumley, D.; Karwowski, P.; Jung, M.K.; Kao, J. Prognostic role of baseline neutrophil-to-lymphocyte ratio in metastatic solid tumors. Mol. Clin. Oncol. 2020, 13, 25. [CrossRef] [PubMed]

102. Guthrie, G.J.; Charles, K.A.; Roxburgh, C.S.; Horgan, P.G.; McMillan, D.C.; Clarke, S.J. The systemic inflammation-based neutrophil-lymphocyte ratio: Experience in patients with cancer. Crit. Rev. Oncol. Hematol. 2013, 88, 218-230. [CrossRef] [PubMed]

103. Schmidt, H.; Bastholt, L.; Geertsen, P.; Christensen, I.J.; Larsen, S.; Gehl, J.; Von der Maase, H. Elevated neutrophil and monocyte counts in peripheral blood are associated with poor survival in patients with metastatic melanoma: A prognostic model. Br. J. Cancer 2005, 93, 273-278. [CrossRef] 
104. Liu, H.; Tabuchi, T.; Takemura, A.; Kasuga, T.; Motohashi, G.; Hiraishi, K.; Katano, M.; Nakada, I.; Ubukata, H.; Tabuchi, T. The granulocyte/lymphocyte ratio as an independent predictor of tumour growth, metastasis and progression: Its clinical applications. Mol. Med. Rep. 2008, 1, 699-704. [CrossRef] [PubMed]

105. Sagiv, J.Y.; Michaeli, J.; Assi, S.; Mishalian, I.; Kisos, H.; Levy, L.; Damti, P.; Lumbroso, D.; Polyansky, L.; Sionov, R.V.; et al. Phenotypic diversity and plasticity in circulating neutrophil subpopulations in cancer. Cell Rep. 2015, 10, 562-573. [CrossRef] [PubMed]

106. Daley, J.M.; Thomay, A.A.; Connolly, M.D.; Reichner, J.S.; Albina, J.E. Use of Ly6G-specific monoclonal antibody to deplete neutrophils in mice. J. Leukoc. Biol. 2008, 83, 64-70. [CrossRef] [PubMed]

107. Granot, Z.; Henke, E.; Comen, E.A.; King, T.A.; Norton, L.; Benezra, R. Tumor entrained neutrophils inhibit seeding in the premetastatic lung. Cancer Cell 2011, 20, 300-314. [CrossRef] [PubMed]

108. Casbon, A.J.; Reynaud, D.; Park, C.; Khuc, E.; Gan, D.D.; Schepers, K.; Passegue, E.; Werb, Z. Invasive breast cancer reprograms early myeloid differentiation in the bone marrow to generate immunosuppressive neutrophils. Proc. Natl. Acad. Sci. USA 2015, 112, E566-575. [CrossRef]

109. Jamieson, T.; Clarke, M.; Steele, C.W.; Samuel, M.S.; Neumann, J.; Jung, A.; Huels, D.; Olson, M.F.; Das, S.; Nibbs, R.J.; et al. Inhibition of CXCR2 profoundly suppresses inflammation-driven and spontaneous tumorigenesis. J. Clin. Investig. 2012, 122, 3127-3144. [CrossRef]

110. Wislez, M.; Fujimoto, N.; Izzo, J.G.; Hanna, A.E.; Cody, D.D.; Langley, R.R.; Tang, H.; Burdick, M.D.; Sato, M.; Minna, J.D.; et al. High expression of ligands for chemokine receptor CXCR2 in alveolar epithelial neoplasia induced by oncogenic kras. Cancer Res. 2006, 66, 4198-4207. [CrossRef]

111. Steele, C.W.; Karim, S.A.; Leach, J.D.G.; Bailey, P.; Upstill-Goddard, R.; Rishi, L.; Foth, M.; Bryson, S.; McDaid, K.; Wilson, Z.; et al. CXCR2 Inhibition Profoundly Suppresses Metastases and Augments Immunotherapy in Pancreatic Ductal Adenocarcinoma. Cancer Cell 2016, 29, 832-845. [CrossRef] [PubMed]

112. Yu, P.F.; Huang, Y.; Han, Y.Y.; Lin, L.Y.; Sun, W.H.; Rabson, A.B.; Wang, Y.; Shi, Y.F. TNFalpha-activated mesenchymal stromal cells promote breast cancer metastasis by recruiting CXCR2(+) neutrophils. Oncogene 2017, 36, 482-490. [CrossRef] [PubMed]

113. Wada, Y.; Yoshida, K.; Tsutani, Y.; Shigematsu, H.; Oeda, M.; Sanada, Y.; Suzuki, T.; Mizuiri, H.; Hamai, Y.; Tanabe, K.; et al. Neutrophil elastase induces cell proliferation and migration by the release of TGF-alpha, PDGF and VEGF in esophageal cell lines. Oncol. Rep. 2007, 17, 161-167.

114. Spiegel, A.; Brooks, M.W.; Houshyar, S.; Reinhardt, F.; Ardolino, M.; Fessler, E.; Chen, M.B.; Krall, J.A.; DeCock, J.; Zervantonakis, I.K.; et al. Neutrophils Suppress Intraluminal NK Cell-Mediated Tumor Cell Clearance and Enhance Extravasation of Disseminated Carcinoma Cells. Cancer Discov. 2016, 6, 630-649. [CrossRef]

115. Cools-Lartigue, J.; Spicer, J.; McDonald, B.; Gowing, S.; Chow, S.; Giannias, B.; Bourdeau, F.; Kubes, P.; Ferri, L. Neutrophil extracellular traps sequester circulating tumor cells and promote metastasis. J. Clin. Investig. 2013. [CrossRef]

116. Tohme, S.; Yazdani, H.O.; Al-Khafaji, A.B.; Chidi, A.P.; Loughran, P.; Mowen, K.; Wang, Y.; Simmons, R.L.; Huang, H.; Tsung, A. Neutrophil Extracellular Traps Promote the Development and Progression of Liver Metastases after Surgical Stress. Cancer Res. 2016, 76, 1367-1380. [CrossRef]

117. Clark, R.A.; Klebanoff, S.J. Neutrophil-mediated tumor cell cytotoxicity: Role of the peroxidase system. J. Exp. Med. 1975, 141, 1442-1447. [CrossRef]

118. Koga, Y.; Matsuzaki, A.; Suminoe, A.; Hattori, H.; Hara, T. Neutrophil-derived TNF-related apoptosis-inducing ligand (TRAIL): A novel mechanism of antitumor effect by neutrophils. Cancer Res. 2004, 64, 1037-1043. [CrossRef]

119. Fridlender, Z.G.; Sun, J.; Kim, S.; Kapoor, V.; Cheng, G.; Ling, L.; Worthen, G.S.; Albelda, S.M. Polarization of tumor-associated neutrophil phenotype by TGF-beta: "N1" versus "N2" TAN. Cancer Cell 2009, 16, 183-194. [CrossRef]

120. Yan, B.; Wei, J.J.; Yuan, Y.; Sun, R.; Li, D.; Luo, J.; Liao, S.J.; Zhou, Y.H.; Shu, Y.; Wang, Q.; et al. IL-6 cooperates with G-CSF to induce protumor function of neutrophils in bone marrow by enhancing STAT3 activation. J. Immunol. 2013, 190, $5882-5893$. [CrossRef] [PubMed]

121. Zou, J.M.; Qin, J.; Li, Y.C.; Wang, Y.; Li, D.; Shu, Y.; Luo, C.; Wang, S.S.; Chi, G.; Guo, F.; et al. IL-35 induces N2 phenotype of neutrophils to promote tumor growth. Oncotarget 2017, 8, 33501-33514. [CrossRef] [PubMed]

122. Andzinski, L.; Kasnitz, N.; Stahnke, S.; Wu, C.F.; Gereke, M.; Von Kockritz-Blickwede, M.; Schilling, B.; Brandau, S.; Weiss, S.; Jablonska, J. Type I IFNs induce anti-tumor polarization of tumor associated neutrophils in mice and human. Int. J. Cancer 2016, 138, 1982-1993. [CrossRef]

123. Medina-Echeverz, J.; Fioravanti, J.; Zabala, M.; Ardaiz, N.; Prieto, J.; Berraondo, P. Successful colon cancer eradication after chemoimmunotherapy is associated with profound phenotypic change of intratumoral myeloid cells. J. Immunol. 2011, 186, 807-815. [CrossRef]

124. Mishalian, I.; Bayuh, R.; Eruslanov, E.; Michaeli, J.; Levy, L.; Zolotarov, L.; Singhal, S.; Albelda, S.M.; Granot, Z.; Fridlender, Z.G. Neutrophils recruit regulatory T-cells into tumors via secretion of CCL17-A new mechanism of impaired antitumor immunity. Int. J. Cancer 2014, 135, 1178-1186. [CrossRef] [PubMed]

125. Munitz, A.; Bachelet, I.; Fraenkel, S.; Katz, G.; Mandelboim, O.; Simon, H.U.; Moretta, L.; Colonna, M.; Levi-Schaffer, F. 2B4 (CD244) is expressed and functional on human eosinophils. J. Immunol. 2005, 174, 110-118. [CrossRef] 
126. Lucarini, V.; Ziccheddu, G.; Macchia, I.; La Sorsa, V.; Peschiaroli, F.; Buccione, C.; Sistigu, A.; Sanchez, M.; Andreone, S.; D'Urso, M.T.; et al. IL-33 restricts tumor growth and inhibits pulmonary metastasis in melanoma-bearing mice through eosinophils. Oncoimmunology 2017, 6, e1317420. [CrossRef] [PubMed]

127. Gatault, S.; Delbeke, M.; Driss, V.; Sarazin, A.; Dendooven, A.; Kahn, J.E.; Lefevre, G.; Capron, M. IL-18 Is Involved in EosinophilMediated Tumoricidal Activity against a Colon Carcinoma Cell Line by Upregulating LFA-1 and ICAM-1. J. Immunol. 2015, 195, 2483-2492. [CrossRef]

128. Kataoka, S.; Konishi, Y.; Nishio, Y.; Fujikawa-Adachi, K.; Tominaga, A. Antitumor activity of eosinophils activated by IL-5 and eotaxin against hepatocellular carcinoma. DNA Cell Biol. 2004, 23, 549-560. [CrossRef]

129. Andreone, S.; Spadaro, F.; Buccione, C.; Mancini, J.; Tinari, A.; Sestili, P.; Gambardella, A.R.; Lucarini, V.; Ziccheddu, G.; Parolini, I.; et al. IL-33 Promotes CD11b/CD18-Mediated Adhesion of Eosinophils to Cancer Cells and Synapse-Polarized Degranulation Leading to Tumor Cell Killing. Cancers 2019, 11, 1664. [CrossRef]

130. Carretero, R.; Sektioglu, I.M.; Garbi, N.; Salgado, O.C.; Beckhove, P.; Hammerling, G.J. Eosinophils orchestrate cancer rejection by normalizing tumor vessels and enhancing infiltration of CD8(+) T cells. Nat. Immunol. 2015, 16, 609-617. [CrossRef]

131. Xie, F.; Liu, L.B.; Shang, W.Q.; Chang, K.K.; Meng, Y.H.; Mei, J.; Yu, J.J.; Li, D.J.; Li, M.Q. The infiltration and functional regulation of eosinophils induced by TSLP promote the proliferation of cervical cancer cell. Cancer Lett. 2015, 364, 106-117. [CrossRef]

132. Zhang, B.; Wei, C.Y.; Chang, K.K.; Yu, J.J.; Zhou, W.J.; Yang, H.L.; Shao, J.; Yu, J.J.; Li, M.Q.; Xie, F. TSLP promotes angiogenesis of human umbilical vein endothelial cells by strengthening the crosstalk between cervical cancer cells and eosinophils. Oncol. Lett. 2017, 14, 7483-7488. [CrossRef]

133. Kratochvill, F.; Neale, G.; Haverkamp, J.M.; Van de Velde, L.A.; Smith, A.M.; Kawauchi, D.; McEvoy, J.; Roussel, M.F.; Dyer, M.A.; Qualls, J.E.; et al. TNF Counterbalances the Emergence of M2 Tumor Macrophages. Cell Rep. 2015, 12, 1902-1914. [CrossRef]

134. Pretlow, T.P.; Keith, E.F.; Cryar, A.K.; Bartolucci, A.A.; Pitts, A.M.; Pretlow, T.G., 2nd; Kimball, P.M.; Boohaker, E.A. Eosinophil infiltration of human colonic carcinomas as a prognostic indicator. Cancer Res. 1983, 43, 2997-3000. [PubMed]

135. Dorta, R.G.; Landman, G.; Kowalski, L.P.; Lauris, J.R.; Latorre, M.R.; Oliveira, D.T. Tumour-associated tissue eosinophilia as a prognostic factor in oral squamous cell carcinomas. Histopathology 2002, 41, 152-157. [CrossRef]

136. Ishibashi, S.; Ohashi, Y.; Suzuki, T.; Miyazaki, S.; Moriya, T.; Satomi, S.; Sasano, H. Tumor-associated tissue eosinophilia in human esophageal squamous cell carcinoma. Anticancer. Res. 2006, 26, 1419-1424. [PubMed]

137. Fujii, M.; Yamashita, T.; Ishiguro, R.; Tashiro, M.; Kameyama, K. Significance of epidermal growth factor receptor and tumor associated tissue eosinophilia in the prognosis of patients with nasopharyngeal carcinoma. Auris Nasus Larynx 2002, $29,175-181$. [CrossRef]

138. Von Wasielewski, R.; Seth, S.; Franklin, J.; Fischer, R.; Hubner, K.; Hansmann, M.L.; Diehl, V.; Georgii, A. Tissue eosinophilia correlates strongly with poor prognosis in nodular sclerosing Hodgkin's disease, allowing for known prognostic factors. Blood 2000, 95, 1207-1213. [CrossRef]

139. Matsushima, T.; Handa, H.; Yokohama, A.; Nagasaki, J.; Koiso, H.; Kin, Y.; Tanaka, Y.; Sakura, T.; Tsukamoto, N.; Karasawa, M.; et al. Prevalence and clinical characteristics of myelodysplastic syndrome with bone marrow eosinophilia or basophilia. Blood 2003, 101, 3386-3390. [CrossRef]

140. Wimazal, F.; Germing, U.; Kundi, M.; Noesslinger, T.; Blum, S.; Geissler, P.; Baumgartner, C.; Pfeilstoecker, M.; Valent, P.; Sperr, W.R. Evaluation of the prognostic significance of eosinophilia and basophilia in a larger cohort of patients with myelodysplastic syndromes. Cancer 2010, 116, 2372-2381. [CrossRef]

141. Denburg, J.A.; Browman, G. Prognostic implications of basophil differentiation in chronic myeloid leukemia. Am. J. Hematol. 1988, 27, 110-114. [CrossRef]

142. Cerny-Reiterer, S.; Ghanim, V.; Hoermann, G.; Aichberger, K.J.; Herrmann, H.; Muellauer, L.; Repa, A.; Sillaber, C.; Walls, A.F.; Mayerhofer, M.; et al. Identification of basophils as a major source of hepatocyte growth factor in chronic myeloid leukemia: A novel mechanism of BCR-ABL1-independent disease progression. Neoplasia 2012, 14, 572-584. [CrossRef]

143. Liu, Q.; Luo, D.; Cai, S.; Li, Q.; Li, X. Circulating basophil count as a prognostic marker of tumor aggressiveness and survival outcomes in colorectal cancer. Clin. Transl. Med. 2020, 9, 6. [CrossRef]

144. Rosner, S.; Kwong, E.; Shoushtari, A.N.; Friedman, C.F.; Betof, A.S.; Brady, M.S.; Coit, D.G.; Callahan, M.K.; Wolchok, J.D.; Chapman, P.B.; et al. Peripheral blood clinical laboratory variables associated with outcomes following combination nivolumab and ipilimumab immunotherapy in melanoma. Cancer Med. 2018, 7, 690-697. [CrossRef] [PubMed]

145. Wang, C.; Chen, Y.G.; Gao, J.L.; Lyu, G.Y.; Su, J.; Zhang, Q.I.; Ji, X.; Yan, J.Z.; Qiu, Q.L.; Zhang, Y.L.; et al. Low local blood perfusion, high white blood cell and high platelet count are associated with primary tumor growth and lung metastasis in a $4 \mathrm{~T} 1$ mouse breast cancer metastasis model. Oncol. Lett. 2015, 10, 754-760. [CrossRef] [PubMed]

146. Gabrilovich, D.I.; Nagaraj, S. Myeloid-derived suppressor cells as regulators of the immune system. Nat. Rev. Immunol. 2009, 9, 162-174. [CrossRef] [PubMed]

147. Serafini, P.; Borrello, I.; Bronte, V. Myeloid suppressor cells in cancer: Recruitment, phenotype, properties, and mechanisms of immune suppression. Semin. Cancer Biol. 2006, 16, 53-65. [CrossRef]

148. Greten, T.F.; Manns, M.P.; Korangy, F. Myeloid derived suppressor cells in human diseases. Int. Immunopharmacol. 2011, 11, 802-807. [CrossRef] 
149. Diaz-Montero, C.M.; Salem, M.L.; Nishimura, M.I.; Garrett-Mayer, E.; Cole, D.J.; Montero, A.J. Increased circulating myeloidderived suppressor cells correlate with clinical cancer stage, metastatic tumor burden, and doxorubicin-cyclophosphamide chemotherapy. Cancer Immunol. Immunother. 2009, 58, 49-59. [CrossRef] [PubMed]

150. Mantovani, A. The growing diversity and spectrum of action of myeloid-derived suppressor cells. Eur. J. Immunol. 2010, 40, 3317-3320. [CrossRef]

151. Cui, T.X.; Kryczek, I.; Zhao, L.; Zhao, E.; Kuick, R.; Roh, M.H.; Vatan, L.; Szeliga, W.; Mao, Y.; Thomas, D.G.; et al. Myeloid-derived suppressor cells enhance stemness of cancer cells by inducing microRNA101 and suppressing the corepressor CtBP2. Immunity 2013, 39, 611-621. [CrossRef] [PubMed]

152. Marigo, I.; Bosio, E.; Solito, S.; Mesa, C.; Fernandez, A.; Dolcetti, L.; Ugel, S.; Sonda, N.; Bicciato, S.; Falisi, E.; et al. Tumor-induced tolerance and immune suppression depend on the C/EBPbeta transcription factor. Immunity 2010, 32, 790-802. [CrossRef] [PubMed]

153. Song, X.; Krelin, Y.; Dvorkin, T.; Bjorkdahl, O.; Segal, S.; Dinarello, C.A.; Voronov, E.; Apte, R.N. CD11b+/Gr-1+ immature myeloid cells mediate suppression of T cells in mice bearing tumors of IL-1beta-secreting cells. J. Immunol. 2005, 175, 8200-8208. [CrossRef] [PubMed]

154. Sinha, P.; Clements, V.K.; Fulton, A.M.; Ostrand-Rosenberg, S. Prostaglandin E2 promotes tumor progression by inducing myeloid-derived suppressor cells. Cancer Res. 2007, 67, 4507-4513. [CrossRef] [PubMed]

155. Toh, B.; Wang, X.; Keeble, J.; Sim, W.J.; Khoo, K.; Wong, W.C.; Kato, M.; Prevost-Blondel, A.; Thiery, J.P.; Abastado, J.P. Mesenchymal transition and dissemination of cancer cells is driven by myeloid-derived suppressor cells infiltrating the primary tumor. PLoS Biol. 2011, 9, e1001162. [CrossRef]

156. Yang, L.; DeBusk, L.M.; Fukuda, K.; Fingleton, B.; Green-Jarvis, B.; Shyr, Y.; Matrisian, L.M.; Carbone, D.P.; Lin, P.C. Expansion of myeloid immune suppressor Gr+CD11b+ cells in tumor-bearing host directly promotes tumor angiogenesis. Cancer Cell 2004, 6, 409-421. [CrossRef]

157. Kujawski, M.; Kortylewski, M.; Lee, H.; Herrmann, A.; Kay, H.; Yu, H. Stat3 mediates myeloid cell-dependent tumor angiogenesis in mice. J. Clin. Investig. 2008, 118, 3367-3377. [CrossRef]

158. Rodriguez, P.C.; Quiceno, D.G.; Zabaleta, J.; Ortiz, B.; Zea, A.H.; Piazuelo, M.B.; Delgado, A.; Correa, P.; Brayer, J.; Sotomayor, E.M.; et al. Arginase I production in the tumor microenvironment by mature myeloid cells inhibits T-cell receptor expression and antigen-specific T-cell responses. Cancer Res. 2004, 64, 5839-5849. [CrossRef]

159. Srivastava, M.K.; Sinha, P.; Clements, V.K.; Rodriguez, P.; Ostrand-Rosenberg, S. Myeloid-derived suppressor cells inhibit T-cell activation by depleting cystine and cysteine. Cancer Res. 2010, 70, 68-77. [CrossRef]

160. Nagaraj, S.; Gupta, K.; Pisarev, V.; Kinarsky, L.; Sherman, S.; Kang, L.; Herber, D.L.; Schneck, J.; Gabrilovich, D.I. Altered recognition of antigen is a mechanism of CD8+ T cell tolerance in cancer. Nat. Med. 2007, 13, 828-835. [CrossRef] [PubMed]

161. Kusmartsev, S.; Nagaraj, S.; Gabrilovich, D.I. Tumor-associated CD8+ T cell tolerance induced by bone marrow-derived immature myeloid cells. J. Immunol. 2005, 175, 4583-4592. [CrossRef]

162. Huang, B.; Pan, P.Y.; Li, Q.; Sato, A.I.; Levy, D.E.; Bromberg, J.; Divino, C.M.; Chen, S.H. Gr-1+CD115+ immature myeloid suppressor cells mediate the development of tumor-induced T regulatory cells and T-cell anergy in tumor-bearing host. Cancer Res. 2006, 66, 1123-1131. [CrossRef] [PubMed]

163. Movahedi, K.; Guilliams, M.; Van den Bossche, J.; Van den Bergh, R.; Gysemans, C.; Beschin, A.; De Baetselier, P.; Van Ginderachter, J.A. Identification of discrete tumor-induced myeloid-derived suppressor cell subpopulations with distinct $\mathrm{T}$ cell-suppressive activity. Blood 2008, 111, 4233-4244. [CrossRef]

164. Youn, J.I.; Nagaraj, S.; Collazo, M.; Gabrilovich, D.I. Subsets of myeloid-derived suppressor cells in tumor-bearing mice. J. Immunol. 2008, 181, 5791-5802. [CrossRef] [PubMed]

165. Youn, J.I.; Collazo, M.; Shalova, I.N.; Biswas, S.K.; Gabrilovich, D.I. Characterization of the nature of granulocytic myeloid-derived suppressor cells in tumor-bearing mice. J. Leukoc. Biol. 2012, 91, 167-181. [CrossRef] [PubMed]

166. Schmielau, J.; Finn, O.J. Activated granulocytes and granulocyte-derived hydrogen peroxide are the underlying mechanism of suppression of t-cell function in advanced cancer patients. Cancer Res. 2001, 61, 4756-4760.

167. Mazzoni, A.; Bronte, V.; Visintin, A.; Spitzer, J.H.; Apolloni, E.; Serafini, P.; Zanovello, P.; Segal, D.M. Myeloid suppressor lines inhibit T cell responses by an NO-dependent mechanism. J. Immunol. 2002, 168, 689-695. [CrossRef] [PubMed]

168. Correia, A.L.; Bissell, M.J. The tumor microenvironment is a dominant force in multidrug resistance. Drug Resist. Updat. 2012, 15, 39-49. [CrossRef]

169. Nakasone, E.S.; Askautrud, H.A.; Kees, T.; Park, J.H.; Plaks, V.; Ewald, A.J.; Fein, M.; Rasch, M.G.; Tan, Y.X.; Qiu, J.; et al. Imaging tumor-stroma interactions during chemotherapy reveals contributions of the microenvironment to resistance. Cancer Cell 2012, 21, 488-503. [CrossRef]

170. Ruffell, B.; Coussens, L.M. Macrophages and therapeutic resistance in cancer. Cancer Cell 2015, 27, 462-472. [CrossRef]

171. Shree, T.; Olson, O.C.; Elie, B.T.; Kester, J.C.; Garfall, A.L.; Simpson, K.; Bell-McGuinn, K.M.; Zabor, E.C.; Brogi, E.; Joyce, J.A. Macrophages and cathepsin proteases blunt chemotherapeutic response in breast cancer. Genes Dev. 2011, 25, 2465-2479. [CrossRef]

172. Paulus, P.; Stanley, E.R.; Schafer, R.; Abraham, D.; Aharinejad, S. Colony-stimulating factor-1 antibody reverses chemoresistance in human MCF-7 breast cancer xenografts. Cancer Res. 2006, 66, 4349-4356. [CrossRef] 
173. Ries, C.H.; Cannarile, M.A.; Hoves, S.; Benz, J.; Wartha, K.; Runza, V.; Rey-Giraud, F.; Pradel, L.P.; Feuerhake, F.; Klaman, I.; et al. Targeting tumor-associated macrophages with anti-CSF-1R antibody reveals a strategy for cancer therapy. Cancer Cell 2014, 25, 846-859. [CrossRef] [PubMed]

174. Pyonteck, S.M.; Akkari, L.; Schuhmacher, A.J.; Bowman, R.L.; Sevenich, L.; Quail, D.F.; Olson, O.C.; Quick, M.L.; Huse, J.T.; Teijeiro, V.; et al. CSF-1R inhibition alters macrophage polarization and blocks glioma progression. Nat. Med. 2013, 19, 1264-1272. [CrossRef]

175. Yan, D.; Kowal, J.; Akkari, L.; Schuhmacher, A.J.; Huse, J.T.; West, B.L.; Joyce, J.A. Inhibition of colony stimulating factor-1 receptor abrogates microenvironment-mediated therapeutic resistance in gliomas. Oncogene 2017, 36, 6049-6058. [CrossRef] [PubMed]

176. Wesolowski, R.; Sharma, N.; Reebel, L.; Rodal, M.B.; Peck, A.; West, B.L.; Marimuthu, A.; Severson, P.; Karlin, D.A.; Dowlati, A.; et al. Phase Ib study of the combination of pexidartinib (PLX3397), a CSF-1R inhibitor, and paclitaxel in patients with advanced solid tumors. Adv. Med. Oncol. 2019, 11, 1758835919854238. [CrossRef]

177. Jalalvand, M.; Darbeheshti, F.; Rezaei, N. Immune checkpoint inhibitors: Review of the existing evidence and challenges in breast cancer. Immunotherapy 2021, 13, 587-603. [CrossRef] [PubMed]

178. Darvin, P.; Toor, S.M.; Sasidharan Nair, V.; Elkord, E. Immune checkpoint inhibitors: Recent progress and potential biomarkers. Exp. Mol. Med. 2018, 50,1-11. [CrossRef]

179. Meyer, C.; Cagnon, L.; Costa-Nunes, C.M.; Baumgaertner, P.; Montandon, N.; Leyvraz, L.; Michielin, O.; Romano, E.; Speiser, D.E. Frequencies of circulating MDSC correlate with clinical outcome of melanoma patients treated with ipilimumab. Cancer Immunol. Immunother. 2014, 63, 247-257. [CrossRef]

180. Weber, J.; Gibney, G.; Kudchadkar, R.; Yu, B.; Cheng, P.; Martinez, A.J.; Kroeger, J.; Richards, A.; McCormick, L.; Moberg, V.; et al. Phase I/II Study of Metastatic Melanoma Patients Treated with Nivolumab Who Had Progressed after Ipilimumab. Cancer Immunol. Res. 2016, 4, 345-353. [CrossRef]

181. Highfill, S.L.; Cui, Y.; Giles, A.J.; Smith, J.P.; Zhang, H.; Morse, E.; Kaplan, R.N.; Mackall, C.L. Disruption of CXCR2-mediated MDSC tumor trafficking enhances anti-PD1 efficacy. Sci. Transl. Med. 2014, 6, 237ra267. [CrossRef] [PubMed]

182. Noman, M.Z.; Desantis, G.; Janji, B.; Hasmim, M.; Karray, S.; Dessen, P.; Bronte, V.; Chouaib, S. PD-L1 is a novel direct target of HIF-1alpha, and its blockade under hypoxia enhanced MDSC-mediated T cell activation. J. Exp. Med. 2014, 211, 781-790. [CrossRef]

183. Sun, L.; Clavijo, P.E.; Robbins, Y.; Patel, P.; Friedman, J.; Greene, S.; Das, R.; Silvin, C.; Van Waes, C.; Horn, L.A.; et al. Inhibiting myeloid-derived suppressor cell trafficking enhances T cell immunotherapy. JCI Insight 2019, 4. [CrossRef] [PubMed]

184. Falchook, G.S.; Peeters, M.; Rottey, S.; Dirix, L.Y.; Obermannova, R.; Cohen, J.E.; Perets, R.; Frommer, R.S.; Bauer, T.M.; Wang, J.S.; et al. A phase 1a/1b trial of CSF-1R inhibitor LY3022855 in combination with durvalumab or tremelimumab in patients with advanced solid tumors. Investig. New Drugs 2021, 1-14. [CrossRef] 